\title{
"FAR FROM THE TURBULENT SPACE": CONSIDERING THE ADEQUACY OF COUNSEL IN THE REPRESENTATION OF INDIVIDUALS ACCUSED OF BEING SEXUALLY VIOLENT PREDATORS
}

\author{
HeATHER Ellis CUCOLO AND MichaEl L. PERLIN*
}

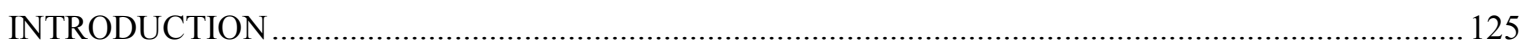

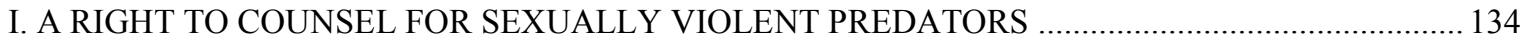

A. Issues Related to Psychometric Tests ............................................................................... 137

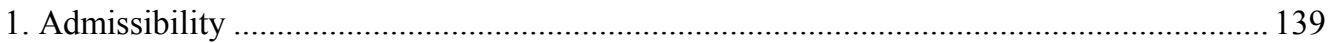

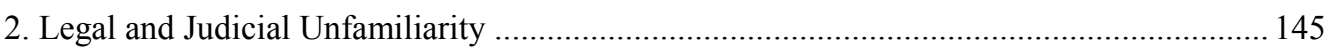

3. Scientific Reliability: Error Rate and Inherent False Positives ....................................... 150

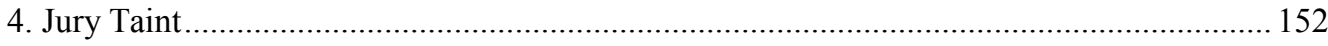

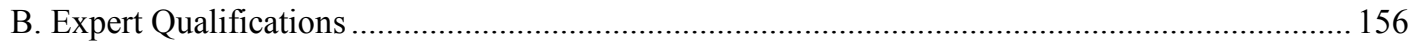

C. Counsel's Responsibilities ......................................................................................... 158

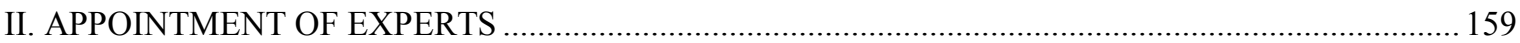

A. The Defendant's Right to an Expert: Ake v. Oklahoma ............................................................. 159

B. Despised Populations ........................................................................................................ 163

C. The Need for a More Rigorous Advocacy Standard ....................................................... 164

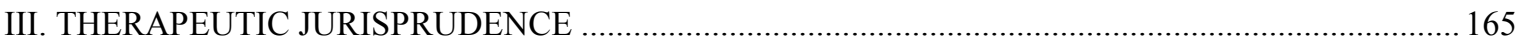

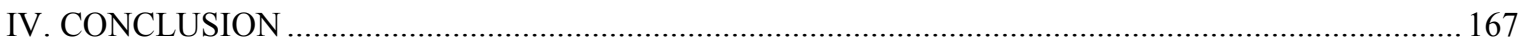

\section{INTRODUCTION}

For the past thirty years, the standard outlined by the United States Supreme Court in Strickland $v$. Washington ${ }^{1}$ has governed the question of adequacy of counsel in criminal trials. There, in a Sixth Amendment analysis, the Supreme Court acknowledged that simply assigning a lawyer to a defendant is not per se constitutionally adequate, and that the lawyer must provide "effective assistance of counsel"- -effectiveness being defined, pallidly, as requiring only that counsel's efforts be "reasonable" under the circumstances. ${ }^{2}$ The benchmark for judging an

\footnotetext{
* Heather Cucolo is Adjunct Professor at New York Law School. Michael L. Perlin is Professor of Law, Emeritus, at New York Law School and Director of the Justice Action Center's International Mental Disability Law Reform Project. Portions of this Article were presented at the American Society of Criminology annual meeting in November 2013, and at a faculty workshop at New York Law School in January 2014. The authors wish to thank Katherine Davies and Paul Metcalf for their excellent research assistance.

1466 U.S. 668 (1984).

$2 \quad I d$. at 686 . The Court further explained that "[a] court must indulge a strong presumption that counsel's conduct falls within the wide range of reasonable professional assistance; that is, the defendant must overcome the
} 
ineffectiveness claim is simply "whether counsel's conduct so undermined the proper function of the adversarial process that the trial court cannot be relied on as having produced a just result."3

Although the Court subsequently extended the Strickland standard to apply in cases involving plea bargaining, ${ }^{4}$ plea offers, ${ }^{5}$ sentencing, ${ }^{6}$ and the appellate stages of a case ${ }^{7}$ (as well as to the mitigation stage of death penalty cases), ${ }^{8}$ it has fallen far short of ensuring that counsel is truly adequate ${ }^{9}$ : that she investigate the case, provide the defendant with all the information necessary for the defendant to make informed choices, and mount a vigorous defense at trial. ${ }^{10}$ "There is little evidence disputing Strickland's failure to ensure adequate assistance of counsel for capital defendants. ${ }^{11}$

Examples of cases in which counsel fell clearly short of the mark, yet which were affirmed on appeal-in which Strickland arguments were rejected-are, in some circumstances, jaw-dropping. In one such case, counsel was found to be effective even though he "failed to introduce ballistics evidence to show that the gun taken from [the defendant] when he was arrested was not the murder weapon." ${ }^{12}$ In another case, an attorney was found constitutionally adequate to provide representation to a death-eligible defendant notwithstanding the fact that he had been admitted to the bar for only six months and had never tried a jury case. ${ }^{13}$ Another lawyer was found constitutionally adequate even when, during the middle of the trial, he appeared in court intoxicated and spent a night in jail. ${ }^{14}$

presumption that, under the circumstances, the challenged action "might be considered sound trial strategy." Id. at 689.

$3 \quad I d$. at 686. One of the authors of this article (MLP) critiques the Strickland standard extensively in Mental Disability \& The Death Penalty: The Shame of the States 129-34 (2013).

$4 \quad$ Lafler v. Cooper, 132 S. Ct. 1376, 1390-91 (2012).

5 Missouri v. Frye, 132 S. Ct. 1399, 1408-10 (2012). On why these cases augur a "seismic shift" in Strickland jurisprudence, see Justin F. Marceau, Embracing a New Era of Ineffective Assistance of Counsel, 14 U. PA. J. CONST. L. 1161, 1163 (2012).

6 Glover v. United States, 531 U.S. 198, 200 (2001).

7 Roe v. Flores-Ortega, 528 U.S. 470, 475 (2000).

8 Wiggins v. Smith, 539 U.S. 510, 534-38 (2003).

$9 \quad$ See generally Carissa Byrne Hessick, Ineffective Assistance at Sentencing, 50 B.C. L. REV. 1069 (2009) (analyzing the "ineffective assistance" jurisprudence). For a novel analysis, arguing that indigent reform would best be served by an equal protection analysis rather than a Sixth Amendment analysis, see Lauren Sudeall Lucas, Reclaiming Equality to Reframe Indigent Defense Reform, 97 MINN. L. REV. 1197 (2013).

10 On the question of whether Strickland is the appropriate standard in cases involving a defendant's right to testify, see Daniel J. Capra \& Joseph Tartakovsky, Why Strickland is the Wrong Test for Violations of the Right to Testify, 70 WASH. \& LEE L. REV. 95, 106-123 (2013).

11 See Michael L. Perlin, "The Executioner's Face Is Always Well-Hidden”: The Role of Counsel and the Courts in Determining Who Dies, 41 N.Y.L. SCH. L. REV. 201, 205-06 (1996).

12 Graham v. Collins, 829 F. Supp. 204, 209 (S.D. Tex. 1993), vacated on other grounds sub nom. Graham v. Johnson, 94 F.3d 958 (5th Cir. 1996).

13 See Paradis v. Arave, 954 F.2d 1483, 1490-92 (9th Cir. 1992), vacated, 507 U.S. 1026 (1993), aff'd on remand, 20 F.3d 950 (9th Cir. 1994) (holding that the defendant did not "demonstrate[] that his counsel's representation during the trial was ineffective").

14 Haney v. State, 603 So. 2d 368, 377-78 (Ala. Crim. App. 1991) (concluding that while counsel was found drunk during trial and spent an evening in jail, "there [was] no evidence [that such actions] interfered, in any manner, with 
There is also a significant array of post-Strickland cases involving defendants with potentially viable insanity or incompetency claims, ${ }^{15}$ and it is clear from a reading of these cases and others like them ${ }^{16}$ - cases involving mental status issues outside the ken of most lawyers ${ }^{17}$ that counsel in these cases all too often are little more than what Judge David Bazelon characterized some forty years ago as "walking violations of the Sixth Amendment." 18 There is little evidence to contradict the conclusion of the late Welsh White-a former University of Pittsburgh law professor and leading authority on the death penalty-that "[1]ower courts' application of Strickland has produced appalling results." 19

When Strickland was decided, the Court had before it a felony case, involving a death penalty conviction in multiple homicides. ${ }^{20}$ And certainly, there is nothing more final than a death sentence. The Court has said many times that "death is different" ${ }^{21}$ as a reflection of this and of

the conduct of the defense or prevented counsel from performing any act in reference to the defense that he desired to perform").

15 See, e.g., Cone v. Bell, 556 U.S. 449, 451, 454, 463 (2009); Knowles v. Mirzayance, 556 U.S. 111, 121 22 (2009); see generally Michael L. Perlin \& Valerie R. McClain, “Where Souls Are Forgotten”: Cultural Competencies, Forensic Evaluations and International Human Rights, 15 PSYCHOL., PUB. POL'Y \& L. 257, 261 (2009) (commenting on the "ineffectiveness of counsel in cases involving defendants with potentially viable insanity or incompetency claims").

16 See 1 Michael L. Perlin, Mental Disability Law: Civil \& Criminal § 2B-11.3, at 267-71 (2d ed. 1998).

17 See generally Michael L. Perlin, The Jurisprudence of the InSANity Defense (1994) (unpacking the roots and myths of mental illness and the insanity defense).

18 David L. Bazelon, The Defective Assistance of Counsel, 42 U. CIN. L. REV. 1, 2 (1973). On how Strickland is the "holy grail" of ineffective counsel, see Patrick C. Metze, Speaking Truth to Power: The Obligation of the Courts to Enforce the Right to Counsel at Trial, 45 TEX. TECH. L. REV. 163, 214-15 (2012) (claiming that the benchmark in Strickland "actually more resembles [a] farce-and-mockery-of-justice standard").

19 Welsh S. White, Capital Punishment's Future, 91 Mich. L. REV. 1429, 1436 (1993) (reviewing RAYMOND PATERnOSTER, CAPITAL PUNiShMENT IN AMERICA (1991)). For other scholarly analyses coming to similar conclusions, see Stephen B. Bright, The Death Penalty as the Answer to Crime: Costly, Counterproductive and Corrupting, 31 SANTA ClARA L. REV. 1069, 1078-84 (1996) (exploring examples of deficient representation in death penalty cases); Christine M. Wiseman, Representing the Condemned: A Critique of Capital Punishment, 79 MARQ. L. REV. 731, 742-44 (1996) (stating that "[t]he stories of ineffective assistance in capital cases are legion"); Meredith J. Duncan, The (So-Called) Liability of Criminal Defense Attorneys: A System in Need of Reform, 2002 BYU L. REV. 1, 1820 (2002) (arguing that "a criminally accused's right to the effective assistance of counsel does not have much substance to it at all"). On the question of the right to litigate Strickland claims, see Ty Alper, Toward a Right to Litigate Ineffective Assistance of Counsel, 70 WASH. \& LEE L. REV. 839, 872-73 (2013) (exploring when an individual can present a claim of ineffective assistance of counsel in the context of the Strickland standard).

20466 U.S. at 671-72 (reviewing the facts and stating that "[d]uring a 10-day period in September 1976, respondent planned and committed three groups of crimes, which included three brutal stabbing murders, torture, kidnaping, severe assaults, attempted murders, attempted extortion, and theft"). Strickland was argued in tandem with another effectiveness-of-counsel case, United States v. Cronic, 466 U.S. 648 (1984), a white-collar crime case involving a complex check kiting scheme.

21 See Gregg v. Georgia, 428 U.S. 153, 187 (1976) (Stewart, Powell, \& Stevens, JJ.) (noting that "the penalty of death is different in kind from any other punishment"). This concept has recently been characterized as the "foundational" basis of death penalty jurisprudence. See Sara Breslow, Pleading Guilty to Death: Protecting the Capital Defendant's Sixth Amendment Right to a Jury Sentencing after Entering a Guilty Plea, 98 CORNELL L. REV. 1245,1249 (2013). 
the obligation on the part of courts to ensure that due process is not violated in such a trial. But in Strickland, there was no hint at all as to what its impact might be on other cases that were not criminal prosecutions, but that potentially involved lengthy periods of institutionalization.

Over a decade ago, in In re Mental Health of K.G.F., ${ }^{22}$ the Montana Supreme Court acknowledged that the Strickland standard might not be a sufficient test of adequacy in cases involving involuntary civil commitment, relying on state statutory and constitutional sources to find that "the right to counsel ... provides an individual subject to an involuntary commitment proceeding the right to effective assistance of counsel. In turn, this right affords the individual with the right to raise the allegation of ineffective assistance of counsel in challenging a commitment order." ${ }^{23}$ In assessing what constitutes "effectiveness," the court—startlinglyeschewed the Strickland standard as insufficiently protective of the "liberty interests of individuals such as K.G.F., who may or may not have broken any law, but who, upon the expiration of a ninety-day commitment, must indefinitely bear the badge of inferiority of a once 'involuntarily committed' person with a proven mental disorder." ${ }^{24}$ Importantly, one of the key reasons why Strickland was seen as lacking was the court's conclusion that "reasonable professional assistance"- the linchpin of Strickland-"cannot be presumed in a proceeding that routinely accepts, and even requires, an unreasonably low standard of legal assistance and generally disdains zealous, adversarial confrontation." 25

While no other jurisdiction has yet followed K.G.F.'s lead, ${ }^{26}$ the case remains a powerful statement of how at least one court could "unpack" the proceedings in question and articulate why a more rigorous standard was required. Writing about K.G.F. in 2008, one of the authors of this Article characterized it as "without doubt the most comprehensive decision on the scope and meaning of the right to counsel in this context from any jurisdiction in the world." 27 This was largely because of its willingness to recognize that the Strickland standard might not be sufficient in all cases involving subsequent institutionalization.

In this Article, we are turning our attention to another aspect of the justice system that does not involve a pending criminal prosecution but which can potentially lead to lengthyindeed, lifetime-periods of institutionalization: proceedings that follow the invocation of Sexually Violent Predator Acts ("SVPA"). Under such Acts:

"Sexually violent predator" ["SVP"] means any person who has been convicted of or charged with a sexually violent offense and who suffers from a mental

\footnotetext{
$22 \quad 29$ P.3d 485 (Mont. 2001).

$23 \quad$ Id. at 500.

$24 \quad I d$. at 491.

25 Id. at 492 (citing Michael L. Perlin, Fatal Assumption: A Critical Evaluation of the Role of Counsel in Mental Disability Cases, 16 LAW \& HuM. BEHAV. 39, 53-54 (1992)). The court describes Perlin's article as identifying the "Strickland standard as 'sterile and perfunctory' where 'reasonably effective assistance' is objectively measured by the 'prevailing professional norms."” Id.

261 Michael L. Perlin \& Heather Ellis Cucolo, Mental Disability law: Civil \& Criminal, § 2B11.3, at 96-99 (Supp. 2012).

27 Michael L. Perlin, "I Might Need a Good Lawyer, Could Be Your Funeral, My Trial”: Global Clinical Legal Education and the Right to Counsel in Civil Commitment Cases, 28 WASH. U. J.L. \& POL'Y 241, 245 (2008).
} 
abnormality or personality disorder which makes the person likely to engage in repeat acts of sexual violence. ${ }^{28}$

Such individuals can be committed indefinitely as sexually violent predators; in a significant percentage of these cases, such commitments are basically life sentences. ${ }^{29}$ The Minnesota appellate courts have reversed judgments on the merits in only four civil commitment cases since the adoption of their SVP statute in 1994. ${ }^{30}$ The Supreme Court's decision in Kansas v. Hendricks paved the way for such cases to be classified as "civil" rather than "criminal," because they involve "involuntary civil confinement of a limited subclass of dangerous persons." 31

The question that we seek to address here is this: Does the Strickland standard apply to such cases, or should a more rigorous standard-à la K.G.F.- be employed? ${ }^{32}$ The answer to this question is, we believe, of great importance to the entire criminal justice system (and, of course, to the SVPA system), for multiple reasons. As we discuss below, the entire SVPA process is cloaked in confusion and infused with fear. Are these cases "criminal"? Are they "civil"? Are they a hybrid? Are the people before the court—who are among the most despised individuals in the nation-"worthy" of the assignment of counsel? With resource problems plaguing both the criminal and the civil justice systems, does it make sense to "burn" money to appoint counsel in cases such as these, on behalf of a population whose loathsomeness is seen as a nearly-universal "given"?

Interestingly, there have been multiple cases decided on the failure of counsel to inform a client that a guilty plea in a criminal trial might require the client to register as a sex offender. Courts have split, finding in some cases that this failure rose to the level of ineffectiveness of counsel $^{33}$ because of the severity of the consequences of potential SVPA commitment ${ }^{34}$ - while

28 KAN. STAT. ANN. § 59-29a02 (West 2014) (providing one representative definition of an SVP); see generally KAN. STAT. ANN. §§ 59-29a01 to -29a24 (West 2014) (providing one state's SVPA). On the issue of defining the requisite risk of recidivism in such cases, see Fredrick E. Vars, Delineating Sexual Dangerousness, 50 Hous. L. REV. 855,897 (2013) (arguing that "the risk of sexually violent recidivism within five years must be at least $75 \%$ " to warrant label as SVP and avoid due process issues).

29 See, e.g., Jenny Roberts, The Mythical Divide Between Collateral and Direct Consequences of Criminal Convictions: Involuntary Commitment of “Sexually Violent Predators,” 93 MINN. L. REV. 670, 707 (2008).

30 Sexually Dangerous Person Act of August 31, 1994, ch. 1, art. 1, 1995 Minn. Laws 5, 7-8 (codified as amended at Minn. STAT. ANN. § 253D.02, subdiv. 16 (2013)). See In re Commitment of Lingl, No. A12-0738, 2012 WL 5188139, at*8 (Minn. Ct. App. Oct. 22, 2012); In re Linehan, 518 N.W.2d 609, 614 (Minn. 1994); In re Hince, No. C994-1366, 1994 WL 637755, at*2 (Minn. Ct. App. Nov. 15, 1994); In re Schweninger, 520 N.W.2d 446, 451 (Minn. Ct. App. 1994). See also In re Commitment of Giem, 742 N.W.2d 422, 433 (Minn. 2007) (reversing a finding of civil commitment without prejudice on procedural grounds).

31521 U.S. 346, 357 (1997). One of the authors of this article, Michael L. Perlin, critiques Hendricks extensively in "There's No Success like Failure / and Failure's No Success at All”: Exposing the Pretextuality of Kansas v. Hendricks, 92 Nw. U. L. REV. 1247 (1998). For further critique of the decision in Hendricks, see In re Van Orden, 271 S.W. 3d 579, 592 (Mo. 2008) (Teitelman, J., dissenting) (arguing that Missouri's SVPA cannot be characterized as "remedial," and arguing that it is instead "punitive").

32 For a recent powerful article, arguing that the right to counsel should be robustly expanded in all criminal cases, see John D. King, Beyond "Life and Liberty": The Evolving Right to Counsel, 48 HARV. C.R.-C.L. L. REV. 1 (2013).

33 See, e.g., United States v. Rose, ACM 36508, 2010 WL 4068976, at *4 (A.F. Ct. Crim. App. June 11, 
other courts have rejected these claims, noting that the SVPA proceeding is merely "civil and regulatory in nature." 35 Those cases that found Strickland violations have mostly drawn on the Supreme Court's decision in Padilla v. Kentucky, ${ }^{36}$ which held that counsel's failure to advise his client about the potential immigration and deportation consequences of a guilty plea were to be assessed by the Strickland standard. ${ }^{37}$ By contrast, those courts that rejected application of Strickland have, by and large, limited Padilla to the context of deportation, ${ }^{38}$ and thus inapplicable to SVPA commitments. ${ }^{39}$ Those cases that have applied Strickland, following Padilla, have generally recognized that "lack of knowledge about serious consequences undermines the basic fairness and legitimacy of a guilty plea," ${ }^{40}$ but few cases have extended this

2010), aff'd, 71 M.J. 138 (2012); Calvert v. State, 342 S.W.3d 477 (Tenn. 2011); People v. Fonville, 804 N.W.2d 878, 896 (Mich. Ct. App. 2011); Taylor v. State, 698 S.E.2d 384 (Ga. Ct. App. 2010). In Taylor, the Georgia appellate court relied on American Bar Association standards for criminal justice in support of its position that professional standards require informing defendants of the consequences of guilty pleas in such cases. See Taylor, 698 S.E.2d at 388.

These cases are cited in Colleen Shanahan's Significant Entanglements: A Framework for the Civil Consequences of Criminal Convictions, 49 AM. CRIM. L. REV. 1387, 1424 (2012). See also Colleen Connolly, Sliding Down the Slippery Slope of the Sixth Amendment: Arguments for Interpreting Padilla v. Kentucky Narrowly and Limiting the Burden It Places on the Criminal Justice System, 77 BROOK. L. REV. 745, 777 (2012).

34 State v. Bellamy, 835 A.2d 1231, 1238 (N.J. 2003) (holding that "when the consequence of a plea may be so severe that a defendant may be confined for the remainder of his or her life [under New Jersey's Sexually Violent Predator Act], fundamental fairness demands that the trial court inform defendant of that possible consequence") (emphasis added). For a discussion of this case as a part of a move away from a formalistic distinction between "collateral" and "direct" consequences, see Roberts, supra note 29, at 721.

35 See, e.g., Shanahan, supra note 33, at 1424-1425 n.221, discussing Maxwell v. Larkins, No. 4:08 CV 1896 DDN, 2010 WL 2680333, at *9-10 (E.D. Mo. July 1, 2010), and Robinson v. State, No. A11-550, 2012 WL 118259 , at *4 (Minn. Ct. App. Jan. 17, 2012).

36559 U.S. 356 (2010). In Padilla, although deportation was characterized as "not, in a strict sense, a criminal sanction" and although "removal proceedings are civil in nature," the Court granted that deportation is an especially "severe "penalty," "intimately related to the criminal process." Id. at 365 . On the significance of "ostensibly non-penal sanctions" in general, see Wayne Logan, Informal Collateral Consequences, 88 WASH. L. REV. 1103,1103 (2013). Beyond the scope of this Article is the important question of the special issues raised when a person subject to deportation is mentally ill. See, e.g., Aliza B. Kaplan, Disabled and Disserved: The Right to Counsel for Mentally Disabled Aliens in Removal Proceedings, 26 Geo. Immigr. L.J. 523 (2012); Amelia Wilson \& Natalie H. Prokop, Applying Method to the Madness: The Right to Court Appointed Guardians Ad Litem and Counsel for the Mentally Ill in Immigration Proceedings, 16 U. PA. J.L. \& Soc. ChAnge 1 (2013); Fatma E. Marouf, Incompetent but Deportable: The Case for a Right to Mental Competence in Removal Proceedings, 65 HASTINGS L.J. 929 (2013).

37 Compare Turner v. Rogers, 131 S. Ct. 2507, 2520 (2011) (holding that the due process clause did not automatically require provision of counsel at civil contempt proceeding), with Tom Pryor's criticism in Note, Turner v. Rogers, The Right to Counsel, and the Deficiencies of Mathews v. Eldridge, 97 MinN. L. REV. 1854 (2013). On the question of the application of Strickland to counsel's incorrect advice about parole, see Webb v. State, 334 S.W.3d 126, 130-131 (Mo. 2011) (en banc) (finding that incorrect advice from counsel regarding parole eligibility after plea bargaining was sufficient for a prima facie ineffective assistance claim, and remanding for an evidentiary hearing).

38 See, e.g., Robinson v. State, No. A11-550, 2012 WL 118259, at*4 (Minn. Ct. App. Jan. 17, 2012).

39 See Shanahan, supra note 33, at 1420-21 (discussing cases finding Padilla inapplicable, because there are not "near-automatic outcomes" in SVPA cases, as there are in deportation cases following guilty pleas). On the potential scope of Padilla, see Joanna Rosenberg, A Game-Changer? The Impact of Padilla v. Kentucky on the Collateral Consequences Rule and Ineffective Assistance of Counsel Claims, 82 FORDHAM L. REV. 1407 (2014). 
concept to notification of the consequences of the SVPA. ${ }^{41}$

State v. Myers demonstrates a common approach to due process and knowledge of a state's SVPA during the guilty plea process. ${ }^{42}$ After pleading guilty to sexual assault of a child, Robert Myers moved to withdraw his plea on the grounds that it was not knowing and voluntary because the trial court had failed to inform him about Wisconsin's Sexually Violent Person Commitments Act. ${ }^{43}$ The court noted that because commitment is not an automatic result of the conviction, Myers had no due process right to be informed prior to entering his plea. ${ }^{44}$ Myers arguments have received "a cool reception by the courts," 45 but the case has encouraged prosecutors to include the discussion of these topics as "part of the plea negotiation process and plea colloquy" to avoid potential litigation on this issue. ${ }^{46}$

As Professor Roberts notes:

Involuntary commitment under an SVPA is a clear-cut case in which due process would require a pre-plea warning under . . . [a] proposed reasonableness test. Due to its highly severe nature, any reasonable defendant would place significant weight on the possibility of lifelong involuntary commitment as a sexually violent predator in the decision-making process

40 Roberts, supra note 29, at 721. Professor Roberts further notes that "[i]t is difficult to maintain that a plea without such knowledge is truly a voluntary, knowing, and intelligent act." Id.

41 State v. Bellamy, 835 A.2d 1231, 1235 (N.J. 2003) (holding that "prior to accepting a guilty plea to a predicate offense," trial courts must inform defendants of possible consequences under the Act).

42544 N.W.2d 609 (Wis. Ct. App. 1996).

$43 \quad$ Id. at 610; see Wis. STAT. ANN. § 980.01-.14 (West 2013).

44 Id. at 610-11. See Thomas v. State, 365 S.W. 3d 537, 541 (Tex. Ct. App. 2012) (recognizing that "SVP commitment is neither a penalty nor an automatic result of criminal convictions"); Blaise v. State, No. 10-0466, 801 N.W. 2d 627, at *3 (Iowa Ct. App. May 25, 2011) (holding commitment as a sexually violent predator is "not a definite, immediate, or automatic result" plaintiff's conviction). See also Roberts, supra note 29, at 712. Professor Roberts explains:

The [Myers] court noted that involuntary commitment would not automatically flow from the fact of Myers's conviction. Instead, "Myers will have the full benefit of the [commitment law's] procedures, due process, and an independent trial." Since commitment was thus only a potential future consequence of his plea, Myers had no due process right to know about it prior to entering his plea.

Id.

There is a stark contrast between decisions like this and cases mandating counsel in misdemeanor criminal cases. $C f$. Argersinger v. Hamlin, 407 U.S. 25, 37 (1972) (holding "that absent a knowing and intelligent waiver, no person may be imprisoned for any offense, whether classified as petty, misdemeanor, or felony, unless he was represented by counsel at his trial"); Rodriguez v. Rosenblatt, 277 A.2d 216, 223 (N.J. 1971) (mandating the provision of counsel if, in misdemeanor prosecution, defendant faces "consequence of magnitude," such as loss of driver's license). On how failure to comply with the Argersinger mandate regularly leaves "Gideon's promise . . . unfulfilled," see Erica Hashimoto, The Problem with Misdemeanor Representation, 70 WASH. \& LEE L. REV. 1019, 1047 (2013).

45 Brian K. Holmgren, Sexually Violent Predator Statutes: Implications for Prosecutors and Their Communities, 32 Prosecutor 20, 32 (1998).

$46 \quad I d$. 
leading up to a guilty plea. Not every defendant will ultimately decide, due to the potential for commitment, to reject all plea offers. However, this is information that reasonable defendants will rely upon in making knowledgeable, voluntary decisions about whether to plead guilty to a qualifying offense in the states with SVPAs. ${ }^{47}$

But these cases consider Strickland only within the context of the initial criminal proceeding. ${ }^{48}$ Our focus here is on the SVPA proceeding itself, where there is some case authority holding that there is no constitutional right to counsel. ${ }^{49}$ Of the cases that have considered Strickland challenges (thus assuming a right to representation), virtually all have rejected Strickland-based arguments. ${ }^{50}$

We assert that there is such a right to counsel, but that Strickland-especially given the pallid interpretations of Strickland that have passed constitutional muster in felony cases ${ }^{51}$ - is itself an insufficient predicate for a finding of constitutionality in such proceedings. In the wake of K.G.F., a more searching standard (albeit a different one from K.G.F.) must instead be employed. ${ }^{52}$

We say this for three main reasons: first, SVPA proceedings normally turn on the interpretation of several controversial psychometric tests. ${ }^{53}$ However, there is no evidence that the

$47 \quad$ Roberts, supra note 29 , at 726.

48 See Shanahan, supra note 33, at 1434 ("Courts can ask: is the consequence significant as an objective matter and to the particular defendant, and is the consequence entangled with the criminal process?").

49 See, e.g., Ramsey v. Runion, No. 2:11cv396, 2012 WL 3883378, at *5 (E.D. Va. Sept. 5, 2012) (stating "there is no federally cognizable right to effective assistance of counsel in a civil commitment proceeding"); but see, e.g., People v. Bowles, 932 N.Y.S. 2d 112, 117 (App. Div. 2011) (holding that the right to counsel emanates from Fourteenth Amendment due process clause rather than Sixth Amendment right to counsel clause, because "sex offender adjudication is not part of a criminal action").

50 See infra text accompanying notes 76-78.

51 See, e.g., PERLIN, supra note 3, at 123-38 (discussing cases).

52 For a comprehensive analysis of why Strickland should apply to SVPA cases, see In re Ontiberos, 287 P.3d 855, 867 (Kan. 2012) (applying Strickland "because [the defendant's] right to counsel arises from a constitutional right similar to the rights attendant to a criminal trial").

53 Many independent experts base their predictions heavily on psychometric tests. These tests include "actuarial tests," also known as "future risk assessments," such as the Violence Risk Appraisal Guide ("VRAG"), the Sex Offender Risk Appraisal Guide ("SORAG”), the Rapid Risk Assessment for Sex Offender Recidivism ("RRASOR"), and the Minnesota Sex Offender Screening Tool ("MnSOST-R"). See generally VernON L. QuinseY ET AL., VIOLENT OfFEnders: ApPRAising AND MANAGing RisK (2d ed. 2006); Vernon L. Quinsey et AL., Violent OfFEnders: ApPraising AND MANAGING RISK 141-190 (1998); Grant T. Harris et al., Violent Recidivism of Mentally Disordered Offenders: The Development of a Statistical Prediction Instrument, 20 CRIM. Just. \& BeHAV. 315 (1993); R. Karl Hanson, The Development of a Brief Actuarial Risk Scale FOR SEXUAl OfFense Recidivism 18-19 (1997); Douglas L. Epperson et al., Minnesota Sex Offender Screening Tool-Revised (MnSOST-R) Technical Paper: Development, Validation, and Recommended Risk Level Cut Scores (Dec. 2003), http://rsoresearch.files.wordpress.com /2012/01/ia-state-study.pdf; Richard Hamill, Recidivism of Sex Offenders: What You Need to Know, CRIM. JUST., Winter 2001 , at 24,30 .

An oft-used actuarial test, the Static-99, is a ten-item assessment instrument created by Drs. R. Karl Hanson and David Thornton for use with male sexual offenders who are at least eighteen year of age at the time of their release to the community. It is the most widely implemented sex offender risk assessment instrument in the world, extensively used 
bulk of lawyers involved in such cases have any familiarity with these instruments, or with the literature about their validity and reliability.

Second, although the Supreme Court held in Ake v. Oklahoma ${ }^{54}$ that a defendant has a right to an independent expert in a felony trial, there is very little analogous case or statutory law with regard to SVPA matters. ${ }^{55}$ Thus, counsel may be less likely or able to competently launch a defense in such cases.

Third and finally, the population at issue is the most despised group of individuals in the nation. ${ }^{56}$ Judges, jurors and lawyers share society's general revulsion towards sexually violent predators. ${ }^{57}$ Although the bar pays lip service to the bromide that legal counsel is available for all, no matter how unpopular the cause, the reality is that there are few volunteers for the job of representing these individuals, and that the public's enmity has a chilling effect on legal representation in this area.

For all of these reasons, we propose a new standard in SVPA hearings: to be effective, counsel must demonstrate familiarity with the psychometric tests regularly employed at such hearings, and counsel must have access to relevant expert witnesses at no cost to the person facing sex offender adjudication. This would be done in the same manner envisioned by the Ake Court in

in the United States, Canada, the United Kingdom, Australia, and many European nations. R. Karl Hanson \& David Thornton, Static-99 Tally Sheet, STATIC-99 CLEARINGHOUSE, http://www.static99.org/pdfdocs/static-99-codingrules_e71.pdf (last visited Mar. 2, 2015). According to Dr. Hanson, the RRASOR and Static-99 developmental samples were derived from a limited number of small, non-random samples from mostly Canadian and English institutions, with one U.S. sample included in RRASOR. R. KARL HANSON, THE DEVELOPMENT OF A BRIEF ACTUARIAL RiSK SCALE FOR SEXUAL OFFENSE RECIDIVISM 14 (1997), available at http://www.publications.gc.ca/site/eng/72871/publication.html; see also R. Karl Hanson \& David Thornton, Improving Risk Assessments for Sex Offenders: A Comparison of Three Actuarial Scales, 24 L. \& HuM. BeHAV. 119 (2000); R. Karl Hanson \& Andrew J.R. Harris, Where Should We Intervene? Dynamic Predictors of Sexual Offense Recidivism, 27 CRIM. JuST. \& BEHAV. 6 (2000).

The samples used in the Static-99 tool were revised a handful of times, yet there were still problems in determining risk accurately. R. KARl HANSOn \& Kelley Morton-Bourgon, Predictors of SEXual Recidivism: An UPDATED META-ANALYSIS 32 (2004), available at http://www.static99.org/pdfdocs/hansonandmortonbourgon2004.pdf. The sampled majority was released from maximum-security prisons or mental health institutions, and thus may represent higher risk groups than typical sex offenders. While intending the tools to be applicable on an international scale, there is no sign the developers made any attempt to conduct truly representative sampling to satisfy scientific principles for a more global application. Another issue is the fact that the developmental samples included inconsistent definitions of the outcome variable of recidivism, including charges, readmissions, and/or reconvictions, and used widely varying timeframes for follow-up.

$54 \quad 470$ U.S. $68,85(1985)$.

55 But see Commonwealth v. Curnutte, 871 A.2d 839, 842-44 (Pa. Super. Ct. 2005) (holding that an indigent defendant with private counsel was entitled to a state-funded expert for his sexually violent predator hearing).

$56 \quad$ See Heather Ellis Cucolo \& Michael L. Perlin, Preventing Sex-Offender Recidivism through Therapeutic Jurisprudence Approaches and Specialized Community Integration, 22 TEMP. POL. \& CIV. RTS. L. REV. 1, 4 (2012) ("Currently, no other population is more despised, more vilified, more subject to media misrepresentation, and more likely to be denied basic human rights.").

$57 \quad$ See id.; Kevin J. Breer, Beyond Hendricks: The United States Supreme Court Decision in Kansas v. Crane and Other Issues Concerning Kansas's Sexually Violent Predator Act, J. KAN. B. Ass'N, Apr. 2002, at 13 (“Sex offenders are the scourge of modern America, the 'irredeemable monsters' who prey on the innocent. Although this revulsion is perhaps now more widespread and more acute, it is not unprecedented in the annals of American justice."). 
insanity cases. ${ }^{58}$ Further, we believe that the use of such a standard would best comport with the principles of therapeutic jurisprudence. ${ }^{59}$

This Article will proceed in this manner. First, we will look at the relevant issues that surround the question of the right to counsel in such cases. Then, we will examine the three issues listed above supporting a more stringent effectiveness standard. After that, we will consider the meaning of therapeutic jurisprudence and its application to these cases. We will then offer some modest conclusions.

The title of this Article comes from Bob Dylan's complex song Jokerman. ${ }^{60}$ While discussing the song's meaning, critic Michael Gray points out that it "insist[s] that 'evil' is not 'out there,' among 'the others,' but is inside us all." ${ }^{\prime 61}$ Our refusal to acknowledge this realityand our tendency to see sex offenders as a "less than human" subgroup of "the other" and indeed encourages us, to ignore the issues that we seek to address in this paper. We believe that Bob Dylan's words are therefore crucial to understanding the legal issues we discuss in this Article.

\section{A RIGHT TO COUNSEL FOR SEXUALLY VIOLENT PREDATORS ${ }^{63}$}

An individual facing sex offender civil commitment ${ }^{64}$ may be assigned counsel, but is not necessarily afforded the absolute right to have an appointed attorney. ${ }^{65}$ Jurisdictions vary on the availability and scope of the Sixth Amendment right to counsel. ${ }^{66}$ For instance, in Kansas, if a person is indigent, the state is required to provide her with both the assistance of counsel and

$58 \quad$ See Ake, 470 U.S. at 85.

59 For discussions of the role of therapeutic jurisprudence in the representation of persons alleged to be sexually violent predators, see generally Cucolo \& Perlin, supra note 56, at 31-42; Heather Ellis Cucolo \& Michael L. Perlin, "They're Planting Stories In the Press": The Impact of Media Distortions on Sex Offender Law and Policy, 3 U. DENV. CRIM. L. REV. 185, 240-45 (2013). On therapeutic jurisprudence ("TJ") in this context, see infra Part III.

60 BOB DYLAN, Jokerman, on INFIDELS (Columbia Records 1983). One of the authors (MLP) has explored the meaning of this song in other written works, including in Michael L. Perlin \& Naomi M. Weinstein, "Friend to the Martyr, A Friend to the Woman of Shame”: Thinking About the Law, Shame and Humiliation, 24 S. CAL. REV. L. \& SoC. JUST. 1 (2014).

61 Michael Gray, The Bob Dylan EnCyClopedia 364 (2008).

62 See Cucolo \& Perlin, supra note 56, at 30.

63 This section is adapted from 2 Michael L. Perlin \& Heather E. Cucolo, Mental Disability LaW: CIVIL \& CRIMINAL (3d ed. forthcoming 2015).

64 For a comprehensive consideration of state statutes pertaining to the civil commitment of sex offenders, see NAT'L Dist. AtTorneys ASS'N, Civil COMmitment of SeX OfFenders (Apr. 2012), available at http://www.ndaa.org/pdf/Sex\%20Offender\%20Civil\%20Commitment-April\%202012.pdf.

65 See Ramsey v. Runion, No. 2:11cv396, 2012 WL 3883378, at*5 (E.D. Va. Sept. 12, 2012) (stating that "there is no federally cognizable right to effective assistance of counsel in a civil commitment proceeding").

66 For an example of how one jurisdiction defines the scope of the right to counsel in this context, see In re Commitment of Dodge, 989 N.E.2d 1159, 1167 (Ill. App. Ct. 2013) (measuring a sexually violent defendant's right to effective assistance up to the standards provided in Strickland v. Washington, 466 U.S. 668 (1984) despite that the proceedings were civil in nature). 
examination by mental health professionals. ${ }^{67}$ The individual also receives the right to present and cross-examine witnesses, and the opportunity to review documentary evidence presented by the state. ${ }^{68}$ Yet the right to counsel at each stage in the commitment process is not automatically granted, and has been denied during pre-commitment evaluations ${ }^{69}$ as well as during the psychological evaluation for annual review hearings. ${ }^{70}$ The Kansas Court of Appeals has mandated that if appointed counsel for a committed person under the SVPA is not engaged, not responsive, or otherwise not active, the court is obligated to investigate or to appoint new counsel, because of a clear statutory requirement that counsel be provided "at all stages of the proceedings."

67 See KAN. STAT. ANN. § 59-29a06 (West 2014) (stating that upon the individual's request, the court must determine whether such services are necessary). As to self-representation, see In re Det. of Turay, 986 P.2d 790, 800 (Wash. 1999) (en banc) (holding a defendant must unequivocally request the right to represent himself), cert. denied, 531 U.S. 1125 (2001).

68 KAN. STAT. ANN. § 59-29a07(g) (West 2014).

69 See, e.g., Greenfield v. N.J. Dep’t of Corr., 888 A.2d 507, 507-12 (N.J. Super. Ct. App. Div. 2006) (finding a sex offender had no due process right to review materials or meet with a committee addressing his possible referral to the state's attorney general for commitment as a sexually violent predator).

Notably, New York considers civil management to be a collateral rather than a direct consequence of conviction. See, e.g., People v. Harnett, 945 N.E.2d 439 (N.Y. 2011) (concluding that failure to inform a defendant who pleads guilty to a sex offense of the possibility of being civilly committed under state SVPA does not result in an automatic invalidation of the plea); Project Release v. Prevost, 722 F.2d 960, 976 (2d Cir. 1983) (ruling that legal counsel is not required at pre-hearing psychiatric interviews). Compare Hollis v. Smith, 571 F.2d 685 (2d Cir. 1978) (ruling that defendant is not entitled to counsel at a psychiatric exam), with Ughetto v. Acrish, 518 N.Y.S.2d 398, 405 (N.Y. App. Div. 1987) (ruling that in the absence of a showing that counsel would interfere, he should be permitted to observe the psychiatric examination either directly or indirectly).

Admittedly, a number of courts have concluded that a civil commitment proceeding should not be equated with a criminal prosecution. E.g., Project Release 722 F.2d at 974-75 (stating that the court is "not prepared to invoke the same criminal procedural standards required in the criminal context" for the civil commitment context); see also Goetz v. Crosson, 967 F.2d 29, 34-35 (2d Cir. 1992) (discussing the necessity of prioritizing psychiatric advice in civil commitment cases). However, the rationale for this conclusion is not that the deprivations suffered by an individual subject to the civil commitment process are less severe than those suffered by a convicted criminal defendant, but rather that civil commitment proceedings are less adversarial in nature because one of its purposes is to provide mental health treatment that will benefit the subject of commitment. See Goetz, 967 F.2d at 34-35; Ughetto, 518 N.Y.S.2d at 403.

For an example of the purposes of civil commitment in the context of a child's case, see Parham v. J.R., 442 U.S. 584, 600-01 (1979) ("The state through its voluntary commitment procedures does not 'label' the child; it provides a diagnosis and treatment that medical specialists conclude the child requires.").

70 See In re Det. of Petersen, 980 P.2d 1204, 1217 (Wash. 1999) (ruling that the defendant failed to show that his annual review was invalid "because he was denied the presence of counsel at the examination").

${ }_{71}$ See In re Miles, 213 P.3d 1077, 1083 (Kan. Ct. App. 2009), which quotes from one prisoner's pro se submission to the court:

The problem Petitioners are experiencing is with the attorneys appointed by the Court of Wyandotte County. These attorneys of record rarely, if ever, consult with their clients during the annual review period and almost never send any documentation as to any judgment or action taken in their case. Hence the patient has no alternative to but to file his own petition without the assistance of counsel.

Id. (internal quotations omitted). 
individual has been screened for civil commitment and detained post-conviction, thus implicating a right to effective assistance of counsel in the underlying criminal proceeding. ${ }^{72}$ New Jersey and New York both statutorily mandate that counsel be assigned in the SVPA process once an individual is temporarily committed and awaiting his initial civil commitment hearing or trial. ${ }^{73}$

Questions regarding the quality of counsel and the threshold of constitutional rights have been considered in cases where defendants have sought to withdraw a plea bargain where they were not informed of the potential consequences of a sex offender conviction. The Supreme Court has yet to address this issue, and there is a lack of uniformity in the state courts. New Jersey appears to be one of the only states that requires counsel to inform the defendant that pleading guilty might result in sexual offender civil commitment. ${ }^{74}$ Other state courts have mandated a duty to inform when the plea would result in sexual offender registration while on probation. ${ }^{75}$ Many state courts have determined that civil commitment is merely a collateral consequence and not a direct result of the plea, and therefore there is no duty to inform. ${ }^{76}$ The South Carolina Supreme Court ruled in 2005 that, although the criminal conviction is the triggering event for the state's SVPA, the attorney had no duty to inform the offender about civil commitment before the offender pleaded guilty. ${ }^{77}$ The Kansas Court of Appeals reasoned that, even if the defendant was

72 But see In re McCracken, 551 S.E.2d 235, 240 (S.C. 2001) (finding that the Sixth Amendment was not implicated because the defendant failed to show the case was a criminal proceeding); Collie v. State, 710 So. $2 \mathrm{~d} 1000$, 1012-13 (Fla. Dist. Ct. App. 1998) (finding no constitutional right to counsel under that state's SVPA). See generally Richard Klein, The Emperor Gideon Has No Clothes: The Empty Promise of the Constitutional Right to Effective Assistance of Counsel, 13 HASTINGS CONST. L.Q. 625 (1986) (discussing how underfunding the agencies that provide indigent defense counsel endangers the right to counsel).

73 N.J. STAT. ANN. § 30:4-27.29.a (West 2015) (stating that a person subject to involuntary commitment shall have counsel present at the hearing and shall not be permitted to appear at the hearing without counsel); N.Y. MENTAL HYG. LAW $\S 10.06$ (c) (McKinney 2014) ("Promptly upon the filing of a sex offender civil management petition, ... the court shall appoint counsel in any case where the respondent is financially unable to obtain counsel. The court shall appoint the mental hygiene legal service if possible.").

$74 \quad$ See State v. Bellamy, 835 A.2d 1231, 1236 (N.J. 2003) (finding that prior to accepting a guilty plea to a predicate offense, trial courts must inform defendants of possible consequences of civil commitment under the state's SVPA).

75 See Taylor v. State, 698 S.E.2d 384, 388 (Ga. Ct. App. 2010) (concluding that counsel was constitutionally deficient for failing to advise client that pleading guilty would subject the client to sex offender registration requirements).

76 See, e.g., In re Det. of Bailey, 740 N.E.2d 1146, 1160 (Ill. App. Ct. 2000) (finding that commitment proceedings were civil in nature and thus not improperly used by state to subject offender to greater punishment than was imposed pursuant to plea bargain); In re Det. of Campbell, 986 P.2d 771, 775 (Wash. 1999) (en banc) (explaining that because civil commitment is not criminal punishment, it was not a foregone conclusion that respondent would be civilly committed, and therefore commitment, like sex offender registration, is a collateral consequence of pleading guilty and does not violate the plea agreement), cert. denied, 531 U.S. 1125 (2001); People v. Moore, 81 Cal. Rptr. 2d 658, 661 (Cal. Ct. App. 1998) (holding any commitment the defendant might suffer under the SVPA would not be a direct consequence of his plea); In re Hay, 953 P.2d 666, 676 (Kan. 1998) (finding a "plea agreement is immaterial as far as proceedings under the [SVP] Act are concerned" where commitment is based on a defendant's "mental ailment and present dangerousness"); In re Kunshier, 521 N.W.2d 880, 886 (Minn. Ct. App. 1994) (finding that county did not violate plea agreement by invoking civil commitment statute against patient because it is not criminal punishment, but rather civil treatment).

77 Page v. State, 615 S.E.2d 740, 742 (S.C. 2005). For an insightful look into collateral consequences discussing the Page case, see Roberts, supra note 29, at 693-700. 
informed of the potential for civil commitment, the chance of losing at trial and facing a longer prison sentence would deter a guilty plea retraction. ${ }^{78}$ The question remains whether a defendant's decision to plead guilty takes into account the fact that a potential life sentence attached to civil commitment.

Although securing a constitutional right to counsel in civil commitment is an initial step, it is crucial that we not merely consider the right to counsel, but also that we discuss that right in combination with the quality of counsel and her resources and knowledge in this area of the law. In the following subsections, we will explore the unique circumstances associated with representation of this population, and why a defense attorney needs to have a working knowledge of all of the collateral consequences that might result from committing a sexually motivated offense or being labeled a sexual predator.

\section{A. Issues Related to Psychometric Tests}

Expert predictions of future violence "central to the ultimate question... whether petitioners suffer from a mental abnormality or personality disorder" ${ }^{\text {"79 }}$ are believed to be necessary in the civil commitment of sexual offenders. ${ }^{80}$ The concept that humans can accurately predict the criminal or aberrant behavior of other humans in the long-term future has created the need for the development of actuarial instruments that allegedly remove the "human" element of error when predicting future risk. ${ }^{81}$

In greatly simplified terms, there are two broad approaches to conducting risk assessments to predict future dangerous sexual behavior: clinical judgment and actuarial assessment. $^{82}$ The clinical approach requires evaluators to consider a wide range of risk factors and then form an overall opinion concerning future dangerousness. ${ }^{83}$ The actuarial approach evaluates a limited set of predictors and then combines these variables using a predetermined, numerical weighting system to determine future risk of re-offense, ${ }^{84}$ which may be adjusted (or not) by expert evaluators considering potentially important factors not included in the actuarial measure. $^{85}$

78 Bussell v. State, 963 P.2d 1250, 1254 (Kan. Ct. App. 1998).

79 In re Young, 857 P.2d 989, 1017 (Wash. 1993) (en banc), superseded by statute, WASH. REV. CODE ANN. § 71.09.010-.903 (West 2014), as stated in In re Det. of Thorell, 72 P.3d 708, 720-21 (Wash. 2003) (en banc).

${ }^{80}$ See Thorell, 72 P.3d at 728 (concluding that diagnosis of a mental disorder is not "sufficient for a jury to find that the person presents a serious risk of future sexual violence" unless coupled with additional evidence, including evidence of prior sexually violent behavior" and expert testimony); In re Det. of Holtz, 653 N.W.2d 613, 615 (Iowa Ct. App. 2002) (concluding that if scientific, technical, or other specialized knowledge will assist the trier of fact to understand the evidence or to determine a fact in issue, a witness qualified as an expert by knowledge, skill, experience, training, or education may testify thereto in the form of an opinion or otherwise).

81 See In re Commitment of Burton, 884 So. 2d 1112, 1119 (Fla. Dist. Ct. App. 2004) (Altenbernd, C.J., concurring) (discussing the use of actuarial instruments in predicting future human behavior in violent sex offenders).

82 See, e.g., Dennis M. Doren, Evaluating Sex OfFenders: A MANuAl For Civil Commitments AND BEYOND, 103-04 (2002).
$83 \quad I d$. at 104.
$84 \quad$ Id. at 105 .
$85 \quad$ Id. at $103-104$. 
Courts must contend with finding the correct standard that balances the potential for unfair prejudice against the evidence's probative value. ${ }^{86}$ In spite of the knowledge that testimony predicting the future dangerousness of sexually violent predators is undoubtedly prejudicial, some courts have deemed actuarial assessments as appropriate tools that help the professional draw inferences about the potential for recidivism from historical data, or the collective experience of other professionals who have assessed sex offenders for potential recidivism. ${ }^{87}$ The purpose of actuarial assessment testimony is to assist the fact-finder in determining whether a sexually violent predator is likely to commit future violent acts. Recent case law holds that the probative value of such testimony is significant and directly relevant to whether an individual should be committed as a sexually violent predator. ${ }^{88}$ However, questions as to the ethical usage and accuracy of these predictive instruments remain unanswered, ${ }^{89}$ despite that these tools are widely accepted by the experts who use them. ${ }^{90}$

The introduction of actuarial tools in the risk assessment of sexual offenders has compromised the validity of the forensic psychological testimony presented in such cases, and has pitted experts against one another in a battle to determine which method of prediction is superior. As Florida appellate chief judge Chris Altenbernd explained in his concurring opinion in In re Commitment of Burton, the relevant scientific community that must generally accept these tests in order for them to be admissible in court should include a broader group of clinical and experimental psychologists and psychiatrists - rather than the small and arguably biased subgroup of professionals who earn a living by testifying about their results. ${ }^{91}$ Actuarial approaches use statistical analysis to identify a number of risk factors that assist in the prediction of future dangerousness. Since actuarial models are based on statistical analysis of small sample sizes, they have a variety of potential predictive shortcomings. ${ }^{92}$ The debate rages on, and supporters of both actuarial and clinical assessment tools argue for outright rejection of the other. ${ }^{93}$

$86 \quad$ See generally Burton, 884 So. 2d at 1112 (analyzing, under the Frye standard, the use of psychometric tests to determine future dangerousness of people convicted of sex crimes).

87 See, e.g., State ex rel. Romley v. Fields, 35 P.3d 82, 89 (Ariz. Ct. App. 2001) (admitting actuarial assessments into evidence, but noting that " $[\mathrm{u}]$ nlike DNA and other types of 'scientific' evidence, these risk assessment tools do not have an aura of scientific infallibility ... and their predictive value is far less than $100 \%$ ").

$88 \quad$ In re Girard, 257 P.3d 1256, 1259 (Kan. Ct. App. 2011).

89 See Burton, 884 So. 2d at 1120 (Altenbernd, C.J., concurring) ("I, for one, do not yet have faith that it is wise for the judiciary or for society as a whole to rush down this new path before we are confident that both the science of jurisprudence and the sciences of psychology and psychiatry are up to this awesome task.").

90 In Thorell, the court cited an amicus brief prepared by the Washington Association for the Treatment of Sexual Abusers for the proposition that "the proof of the scientific community's acceptance of actuarial instruments is that the failure to use such instruments constitutes an ethical violation for its members." 72 P.3d at 725 .

91 Burton, 884 So. 2d at 1118 (Altenbernd, C.J., concurring). Judge Altenbernd served as chief judge from 2003 to 2005. See Judge Chris Altenbernd, FlA. 2D. DisT. CT. OF APPEAL, http://www.2dca.org/judges/bio /altenbernd.shtml (last visited Mar. 2, 2015).

92 See Harry M. Hoberman, Dangerousness and Sex Offenders-Assessing Risk for Future Sex Offenses, in 2 The SeXUAL PredATOR, 11-1,11-16 (Anita Schlank ed., 2001).

93 Compare Vernon L. Quinsey et AL., Violent OfFEnders: ApPraising AND MANAgING Risk 171 (1998), with Campbell, 986 P.2d at 787 (seeking to exclude the State's expert's testimony because he "questions the ability for anyone to 'predict dangerousness"'). The Supreme Court of Washington rejected the defendant's argument on the basis of Barefoot v. Estelle, 463 U.S. 880, 896-903 (1983), holding predictions of future dangerousness should be 
The use of actuarial tools raises multiple issues. In a thorough and probing analysis of these tests, Professors Eric Janus and Robert Prentky have concluded that, "to a greater or lesser extent, all ARA ["actuarial risk assessment"] instruments have shortcomings, and these shortcomings detract from the reliability of the instruments." "The authors note that there are three potential sources of prejudice from ARA testimony: first, that the scientific and statistical nature of actuarial assessments will unduly influence the fact-finder into giving it more weight and credibility than it deserves, and that the principle of "actuarial superiority" will exacerbate this tendency; second, that juries will ignore the lack of "fit" between the actuarially-derived risk and the legally relevant risk, thus giving ARA too much weight; and third, that the reality that the "incriminating significance" of statistical probabilities is "obscure." 95

Discussed below are four of the most common issues that have been debated regarding the usage of actuarial instruments: (1) admissibility under evidentiary review standards; (2) lawyers' and judges' familiarity with these tests; (3) concern regarding the potential for juries to confuse or misinterpret the results; and (4) experts' lack of training to administer these tests.

\section{Admissibility}

Generally, the standard of review for admitting expert testimony must satisfy the tests articulated in either Frye v. United States ${ }^{96}$ or Daubert v. Merrell Dow Pharmaceuticals, Inc. ${ }^{97}$ Under the Frye test, novel scientific evidence is admissible when the relevant scientific community has generally accepted the reliability of the underlying theory or principle. ${ }^{98}$ A Frye issue involves a mixed question of law and fact. If the evidence does not involve new scientific principles or methods of proof, a Frye inquiry is unnecessary. ${ }^{99}$ In reviewing a decision based on Frye, an appellate court may look beyond the record to scientific literature and secondary legal

admitted and evaluated by the fact-finder.

The New Jersey Supreme Court has found as fact that actuarial instruments are at least as reliable, if not more so, than clinical interviews. In re C.A., 679 A.2d 1153, 1170-71 (N.J. 1996). For some criticisms of Barefoot, see PERLIN, supra note 3 , at 19-28.

94 Eric S. Janus \& Robert A. Prentky, Forensic Use of Actuarial Risk Assessment with Sex Offenders: Accuracy, Admissibility and Accountability, 40 AM. CRIM. L. REV. 1443, 1472 (2003).

$95 \quad I d$. at 1487.

96293 F. 1013, 1014 (D.C. Cir. 1923) (designating general acceptance by the scientific community as the standard for the admissibility of expert testimony). See also KenNETH R. FOSTER \& PETER W. HubER, JUdGING SCIENCE: SCIENTIFIC KNOWLEDGE AND THE Federal COURTS 225 (1999) (noting that '[t]he 'Frye rule' was applied by federal courts for more than fifty years and is still enforced by many state courts").

97509 U.S. 579, 586-591 (1993) (holding that Federal Rule of Evidence 702 supersedes Frye, and discussing multi-factor test for determining admissibility of expert evidence). Frye has since been superseded in federal courts. See infra note 98.

$98 \quad$ Frye, 293 F. at 1014 ("Just when a scientific principle or discovery crosses the line between the experimental and demonstrable stages is difficult to define. Somewhere in this twilight zone the evidential force of the principle must be recognized, and while courts will go a long way in admitting expert testimony deduced from a wellrecognized scientific principle or discovery, the thing from which the deduction is made must be sufficiently established to have gained general acceptance in the particular field in which it belongs."). See also Thorell, 72 P.3d at 724 (discussing whether actuarial instruments should be viewed as novel scientific evidence).

$99 \quad$ See, e.g., State v. Russell, 882 P.2d 747, 761 (Wash. 1994) (en banc). 
authority. $^{100}$

In Daubert, the Supreme Court rejected Frye's general acceptance test, and instead emphasized the trial judge's independent "gatekeeping" function. ${ }^{101}$ The Daubert test instructs the trier of fact to consider whether (1) the theory or technique is scientific knowledge that can be and has been tested; (2) the theory or technique has been subjected to peer review or publication; (3) the theory or technique has a known or potential rate of error; and (4) the theory or technique is generally accepted within the relevant scientific community. ${ }^{102}$ If a trial court considers these factors, "the court should focus solely on the principles and methodology, not on the conclusions that they generate." ${ }^{103}$ In short, Daubert places the reliability assessment on trial judges, and, in contrast, Frye delegates to the scientific community the duty to determine whether the evidence in question has gained general acceptance. Daubert has been considered by some as potentially more generous than the Frye standard, thus substantively minimizing the role of the general acceptability standard in federal court. ${ }^{104}$

Actuarial tools used in sex offender civil commitment cases have faced a number of challenges ${ }^{105}$ under both Frye ${ }^{106}$ and Daubert. ${ }^{107}$ Under both standards, state courts have generally

100 State v. Copeland, 922 P.2d 1304, 1312 (Wash. 1996) (en banc).

101 Janus \& Prentky, supra note 94, at 1460-61 (highlighting the Court's emphasis on the trial judge's gatekeeping function in "determining at the threshold whether the 'reasoning or methodology underlying the testimony is scientifically valid and whether that reasoning or methodology can be applied to the facts in issue"”).

102 Daubert, 509 U.S. at 593-94; see also id. at 596 (remarking that "[v]igorous cross-examination, presentation of contrary evidence, and careful instruction on the burden of proof are the traditional and appropriate means of attacking shaky but admissible evidence"); see also Janus \& Prenky, supra note 94, at 1462-63 (“A strong argument could be made for requiring a rather high level of reliability for risk assessment testimony. After all, the consequences resting on the assessments are momentous-long-term loss of liberty, on the one hand, and prevention of potential sexual violence on the other. Under such a rigorous standard, it is likely that no risk assessment testimony-clinical or actuarial—would pass muster.”).

103 Daubert, 509 U.S. at 595.

104 See, e.g., James Aaron George, Note, Offender Profiling and Expert Testimony: Scientifically Valid or Glorified Results?, 61 VAND. L. REV. 221, 232-36 (2008) (discussing how Daubert is generally broader than Frye, though federal courts have applied it strictly). But see Melissa Hamilton, Public Safety, Individual Liberty, and Suspect Science: Future Dangerousness Assessments and Sex Offender Laws, 83 TEMP. L. REV. 697, 715-16 (2011) (suggesting that Daubert can be a more limiting standard than Frye in situations where general acceptance of a given method exists, but where the method involves evidence considered specious and thus inadmissible).

On how courts generally "lower the bar" in criminal cases involving Daubert challenges to the state's case, see Paul C. Giannelli, Forensic Science Under the Microscope, 34 OHIO N.U. L. REV. 315, 317 \& n.22 (2008). See also Déirdre Dwyer, (Why) Are Civil and Criminal Expert Evidence Different?, 43 TulSA L. REV. 381, 382-84 (2007).

105 Some challenges have suggested that such actuarial instruments are inadmissible profiling tools because they do nothing more than assign values to characteristics in an effort to fit an individual within a profile, thus purely identifying a person as a member of a group likely to commit a crime. See, e.g., Burton, 884 So. 2d at 1119 (Altenbernd, C.J., concurring) (suggesting that actuarial instruments appear to have a high error rate and may be dysfunctional profiling tools due to the manner in which they assign values to certain characteristics and sort individuals); Thorell, 72 P.3d at 724 (discussing the defendant's argument that actuarial assessment methods are scientifically novel and thus inadmissible under Washington's version of the Frye standard).

106 See David E. Bernstein, Frye, Frye, Again: The Past, Present and Future of the General Acceptance Test, 41 JURIMETRICS J. 385, 401 (2001) (stating that Frye states include Alabama, Arizona, California, Florida, Illinois, Kansas, Maryland, Michigan, Minnesota, Missouri, New Jersey, New York, North Dakota, Pennsylvania, and 
held the most frequently used actuarial tools - the Static-99 and the MnSOST-R - to be admissible. ${ }^{108}$ A majority of these courts found the tests to be reliable on the asserted basis that they are generally accepted by the scientific community, and therefore require no further validation. ${ }^{109}$

In the case of In re Commitment of R.S., the appellate court upheld the trial judge's decision that "the actuarial instruments were admissible in their own right and as the basis of an expert opinion." 110 The court reasoned that, even though other appellate courts had "not specifically and articulately approved actuarials [sic] under Frye," the fact that they accepted

Washington). See, e.g., In re Lourash, 807 N.E.2d 1269, 1275 (Ill. App. Ct. 2004) (holding that a sex offender was entitled to a Frye hearing on the admissibility of any expert testimony predicated on the use of Hansen-Bussière "meta-analysis," the Minnesota Sex Offender Screening Tool-Revised (MnSOST-R), or Static-99 actuarial instruments to measure the risk of recidivism).

107 See Hamilton, supra note 104, at 737 ("The few courts to analyze actuarial risk assessments under Daubert have found them admissible."); Alice B. Lustre, Annotation, Post-Daubert Standards for Admissibility of Scientific and Other Expert Evidence in State Courts, 90 A.L.R.5th 453 (2001) (compiling list of states that apply Daubert or similar tests, states that continue to apply Frye, states that apply some combination of both Daubert and Frye factors, and states that have developed their own tests).

108 See, e.g., In re Det. of Taylor, 134 P.3d 254, 259 (Wash. Ct. App. 2006) (reiterating that actuarial instruments to determine future dangerousness satisfy the Frye standards); Roeling v. State, 880 So. 2d 1234,1240 (Fla. Dist. Ct. App. 2004); Goddard v. State, 144 S.W.3d 848, 853-55 (Mo. Ct. App. 2004); In re Det. of Ashlock, No. 01-1375, 2002 WL 31309497, at*4-5 (Iowa Ct. App. Oct. 16, 2002).

See also Ortega-Mantilla v. State, 898 So. 2d 1164, 1168 (Fla. Dist. Ct. App. 2005) (finding that actuarial instruments consisted of scientific evidence and therefore must pass the Frye test); Burton, 884 So. $2 \mathrm{~d}$ at 1117 (Altenbernd, C.J., concurring) (cautioning that even if actuarial methods passed the Frye test, "the current margin of error in these tests suggests that they may be more unduly prejudicial than probative"); In re Det. of Hargett, 786 N.E.2d 557, 561-62 (Ill. App. Ct. 2003) (holding that a psychologist's testimony based on instruments measuring the respondent's likelihood to re-offend was "actuarial evidence" that should have been examined under the Frye test before being admitted); Jackson v. State, 833 So. 2d 243, 246 (Fla. Dist. Ct. App. 2002) (recognizing implicitly that actuarial instruments were scientific evidence subject to the Frye test for admissibility).

See generally People v. Taylor, 782 N.E.2d 920 (Ill. App. Ct. 2002), abrogated by In re Commitment of Simons, 821 N.E.2d 1184 (Ill. 2004), vacated, 824 N.E.2d 277 (Ill. 2005), remanded to 830 N.E.2d 855 (Ill. App. Ct. 2005) (chronicling the saga in Illinois after a state court initially concluded that the MNSOST-R and Static-99 tests did not satisfy the Frye test for admissibility, and was later instructed by the state supreme court to admit such evidence).

109 See, e.g., In re Det. of Rudolph, No. 48744-2-I, 2004 WL 1328673, at*2-3 (Wash. Ct. App. June 14, 2004); Holtz, 653 N.W.2d at 619 (noting that a review of other jurisdictions regarding the admissibility of actuarial instruments based on scientific reliability led the court to "agree with the recent conclusion of the New Jersey Superior Court that '[o]ur research has revealed no state appellate court decision which has found actuarial instruments inadmissible at SVP proceedings"” (citation omitted)); In re Commitment of R.S., 773 A.2d 72, 96 (N.J. Super. Ct. App. Div. 2001).

Beyond the scope of this Article is a discussion of the stark reality that "in Daubert cases the prosecutor's position is sustained (either in support of questioned expertise or in opposition to it) vastly more often than is that of defense counsel's." Michael L. Perlin, "His Brain Has Been Mismanaged with Great Skill”: How Will Jurors Respond to Neuroimaging Testimony in Insanity Defense Cases?, 42 AKron L. REV. 885, 906-07 (2009). Meanwhile, Professor Susan Rozelle is more blunt: "The game of scientific evidence looks fixed." Susan D. Rozelle, Daubert, Schmaubert: Criminal Defendants and the Short End of the Science Stick, 43 TULSA L. REV. 597, 598 (2007).

110773 A.2d 72, 75 (N.J. Super. Ct. App. Div. 2001). 
these instruments as reliable and helpful sanctioned the New Jersey court's usage. ${ }^{111}$ By further invoking Barefoot v. Estelle, ${ }^{112}$ to which the R.S. court attributed the allowance of evidence regarding future dangerousness based solely on clinical judgment, the R.S. court evaded the reliability question. ${ }^{113}$ Another court, after ruling that neither Daubert nor Frye applied, explained that "where the trier of fact is required by statute to determine whether a person is dangerous or likely to be dangerous, expert prediction may be the only evidence available."114

In State ex rel. Romley v. Fields, ${ }^{115}$ an Arizona court held that "the use of actuarial models by mental health experts to help predict a person's likelihood of recidivism is not the kind of novel scientific evidence or process to which [the Frye test] applies." 116 The court further noted that "unlike DNA and other types of 'scientific' evidence, these risk assessment tools do not have an aura of scientific infallibility .... [but are] subject to interpretation and their predictive value is far less than $100 \% . " 117$ The inconsistency between Daubert and Barefoot on the issue of future dangerousness testimony was acknowledged by the court, but ultimately dismissed. ${ }^{118}$

Courts have denied SVP committees the opportunity to have a Frye or Daubert hearing by employing similar reasoning to that seen in R.S., ${ }^{119}$ and some have found that the accuracy of these tests goes to the weight of the evidence rather than admissibility-especially when such tools are used to form the basis for a testifying expert's opinion concerning the future dangerousness of a sex offender. ${ }^{120}$ Courts have likewise pointed to Barefoot and other cases as holding that the question of reliability in actuarial-assessment testimony goes to the weight of the

\section{$111 \quad$ Id. at $96-97$}

112463 U.S. 880 (1983), superseded by statute, Antiterrorism and Effective Death Penalty Act of 1996, Pub. L. No. 104-132, 110 Stat. 1214, on unrelated grounds as recognized in Slack v. McDaniel, 529 U.S. 473, 483-84 (2000).

113 In re R.S., 773 A.2d at 90 (concluding that since Barefoot accepted reliability of clinical judgment as to future dangerousness, clinical judgment bolstered by actuarial evidence must also be admissible).

114 People v. Ward, 83 Cal. Rptr. 2d 828, 832 (Ct. App. 1999).

11535 P.3d 82 (Ariz. Ct. App. 2001).

$116 \quad I d$. at 89.

$117 \quad I d$.

118 Id. at 88-89 (observing inconsistency between Barefoot and Daubert/Kumho, but finding actuarial evidence admissible on other grounds).

119 In re R.S., 801 A.2d 219, 221 (N.J. 2002) (affirming, while relying upon the analysis of the state appellate court, that "actuarial risk assessment instruments may be admissible in evidence in a civil commitment proceeding under the SVPA when such tools are used in the formation of the basis for a testifying expert's opinion concerning the future dangerousness of a sex offender"). See Thorell, 72 P.3d at 725 (noting that the court's "conclusion is similar to that of other jurisdictions, which have upheld the use of actuarial assessments," before explicitly referencing the New Jersey holdings); Romley, 35 P.3d at 87 (agreeing with other jurisdictions in holding Frye inapplicable to predictions of future dangerousness based upon actuarial instruments). Cf. In re C.A., 679 A.2d at 1170-71 (making no mention of analyzing an actuarial instrument under a Frye or Daubert test).

120 E.g. Holtz, 653 N.W.2d at 619 (relying in part on the logic from R.S., the court held that determining the relevance of actuarial tests implicated "the weight [that] the evidence should receive as opposed to the issue of admissibility"). See also Hamilton, supra note 104, at 735 ("[R]elatively few courts considering the admissibility of RRASOR or Static-99 have conducted any type of reliability analysis, whether Daubert, Frye, or a variant thereof."). 
evidence instead of to admissibility, ${ }^{121}$ and courts have relied on precedent that future dangerousness - regarded as medical testimony-does not constitute scientific evidence for purposes of Frye. ${ }^{122}$ Only where recidivism risk was not at issue, was the Static-99 "not scientifically accepted" for the purpose of determining the requisite "mental abnormality" under the state's civil commitment statute. ${ }^{123}$

One California court explained how Frye is inapplicable to medical testimony:

[This court has] never applied the ... Frye rule to expert medical testimony, even when the witness is a psychiatrist and the subject matter is as esoteric as the reconstitution of a past state of mind or the prediction of future dangerousness, or even the diagnosis of an unusual form of mental illness not listed in the diagnostic manual of the American Psychiatric Association . . . ${ }^{124}$

A defendant facing civil commitment in the state of Washington moved to exclude evidence regarding the results of certain actuarial risk-assessment instruments, including the Violence Risk Assessment Guide and the Minnesota Sex Offender Screening Tool. ${ }^{125}$ A Washington appellate court concluded that the actuarial instruments were generally accepted within the relevant scientific community, based on (1) the expert testimony of both the State and the defendant; (2) the scientific literature; and (3) secondary legal authority. ${ }^{126}$ The Washington Supreme Court confirmed in a subsequent sexual predator commitment review that the use of these instruments as an aid to expert opinion testimony goes to the weight of the evidence rather than to admissibility. ${ }^{127}$ In rendering its decision to admit such testimony without an additional Frye hearing, the court agreed with the authors of an amicus brief that such tools further legitimize the assessment of future risk by "anchor[ing] their risk assessments." 128

121 See, e.g., In re Girard, 257 P.3d at 1259; In re Det. of Hauge, 812 N.E.2d 571, 573 (Ill. App. Ct. 2004); Thorell, 72 P.3d at 725; People v. Litmon, No. H021538, 2002 Cal. App. Unpub. LEXIS 8195, at*56-57 (Cal. Ct. App. Aug. 26, 2002).

122 The courts in the following cases held that the use of actuarial instruments by expert witnesses to help predict a sex offender's likelihood of recidivism in a civil commitment proceeding is not the kind of novel scientific evidence or process to which the Frye test applies: In re Girard, 257 P.3d at 1259; In re Det. of Hauge, 812 N.E.2d 571, 573 (Ill. App. Ct. 2004); People v. Therrian, 6 Cal. Rptr. 3d 415, 419 (Cal. Ct. App. 2003); In re Commitment of Lalor, 661 N.W.2d 898, 903 (Wis. Ct. App. 2003); Jackson v. State, 833 So. 2d 243, 246 (Fla. Dist. Ct. App. 2002) (concluding that the trial court did not err by determining that the actuarial instruments used in that case were "generally accepted in the relevant scientific community as part of the overall risk assessment for sexual predators"); Romley, 35 P.3d at 88-89; In re Det. of Strauss, 20 P.3d 1022, 1025-26 (Wash. Ct. App. 2001); Garcetti v. Superior Court, 102 Cal. Rptr. 2d 214, 238 (2000), rev'd on other grounds sub nom. Cooley v. Superior Court, 127 Cal. Rptr. 2d 177 (2002) (holding that psychiatrist's prediction of future dangerousness is not subject to Frye, regardless of whether the psychiatrist used clinical or actuarial models); Wilson v. Phillips, 86 Cal. Rptr. 2d 204, 207-08 (Cal. Ct. App. 1999).

123 E.g., State v. Rosado, 889 N.Y.S.2d 369, 397 (Sup. Ct. 2009). See also In re Commitment of J.P., 772 A.2d 54, 62 (N.J. Super. Ct. App. Div. 2001) (holding actuarial test invalid as applied to juveniles).

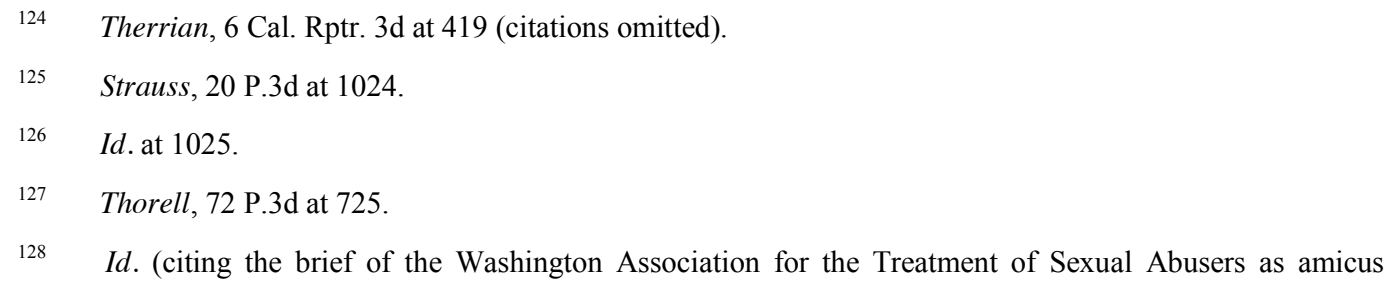


Based on the Illinois Supreme Court holding that "the Frye standard does not demand unanimity, consensus, or even a majority to satisfy the general acceptance test," 129 an Illinois appellate court determined that no error occurred by denying a defendant's motion for a Frye hearing in a sex offender civil commitment case. ${ }^{130}$ A Florida court declined to resolve the issues of whether the actuarial instruments used in sexually violent predator commitment evaluations are subject to a Frye analysis or whether they meet the Frye test, because any error in the admission of the actuarial evidence was deemed harmless - since the experts relied on Appellant's admissions and performed clinical reviews in addition to using actuarial instruments. ${ }^{131}$ Also significant in the court's decision was that the appellant, rather than the State, emphasized the results of the actuarial instruments in closing arguments. ${ }^{132}$

Evidentiary hearing requests have typically been granted only when a new or relatively unknown actuarial tool is introduced. ${ }^{133}$ For example, an Illinois appellate court remanded a case and directed the trial court to conduct a Frye hearing to determine the admissibility of certain actuarial instruments used to measure the likelihood of re-offense. ${ }^{134}$ The court stated that if the Static-99, the MnSOST-R, and the RRASOR satisfied the standard set forth in Frye, then the judgment of the trial court would be affirmed, but if the tests had not gained general acceptance from the psychological and psychiatric communities, the respondent would be entitled to a new trial. ${ }^{135}$ Before the Frye hearing was conducted, the Illinois Supreme Court issued an opinion in In re Commitment of Simons ${ }^{136}$ and noted that "in several jurisdictions[,] actuarial risk assessment is mandated by either statute or regulation." ${ }^{\prime 37}$ Thus, the appellate court's prior order was vacated based on criteria laid out in Simons. ${ }^{138}$ In responding to the state supreme court's remand, the appellate court noted:

(1) [E]xperts in at least 19 other states rely upon actuarial risk assessment in forming their opinions on sex offenders' risks of recidivism; (2) no state outside of Illinois has deemed inadmissible expert testimony based upon such instruments; (3) several jurisdictions actually mandate actuarial risk assessment; and (4) academic literature contains many articles confirming the general

curiae).

129 Donaldson v. Cent. Ill. Pub. Serv. Co., 767 N.E.2d 314, 330 (Ill. 2002), abrogated on other grounds as stated in In re Commitment of Simons, 821 N.E.2d 1184, 1190 (Ill. 2004).

$130 \quad$ In re Det. of Erbe, 800 N.E.2d 137, 153 (Ill. App. Ct. 2003).

131 McQueen v. State, 848 So. 2d 1220, 1220 (Fla. Dist. Ct. App. 2003).

$132 \quad$ Id. at $1220-21$.

133 See, e.g., Det. of Ritter v. State, 312 P.3d 723, 725 (Wash. Ct. App. 2013) (remanding the case to the trial court with directions to conduct a Frye hearing and issue factual findings on the SRA-FV actuarial tool).

$134 \quad$ In re Det. of Traynoff, 338 Ill. App. 3d 949, 965 (Ill. App. Ct. 2003).

135 Id. See In re Det. of Traynoff, 831 N.E.2d 709, 723 (Ill. App. Ct. 2005) (describing the procedural posture of the earlier proceedings).

$136 \quad 821$ N.E.2d 1184 (Ill. 2004).

$137 \quad$ Id. at 1194.

138 Traynoff, 831 N.E.2d at 723. 
acceptance of actuarial risk assessment by professionals who assess sexually violent offenders for risk of recidivism. ${ }^{139}$

Here, the conclusion that actuarial risk assessment has gained general acceptance in the psychological and psychiatric communities was believed to be thoroughly supported by the case law, the statutory law, and the academic literature. ${ }^{140}$

Similarly, a federal district court in Massachusetts summarily admitted actuarial predictions, concluding the standards of general acceptance and peer review had been met. ${ }^{141}$ Meanwhile, an Iowa appellate court affirmed the notion that trial courts may, in their discretion, consider the Daubert factors if deemed helpful in a particular case because "[d]eterminations of admissibility of such evidence must necessarily be made on an ad hoc basis, . . . and it would be impossible to establish rules binding in every case." ${ }^{142}$ Citing the Iowa Supreme Court, the appellate court echoed the concerning yet realistic point that "there is no requirement that the expert be able to express an opinion with absolute certainty." 143

We believe that summary reliance on actuarial tools is error because such tools are still premised on questionable and unconfirmed scientific methods. ${ }^{144}$ The severe consequence resulting from these courts' decisions - blindly allowing for testimony based on actuarial findings - is the potential lifetime deprivation of an individual's liberty. Therefore, relying on less than "absolute certainty" is difficult to accept.

\section{Legal and Judicial Unfamiliarity}

Another concern is the potential for judges and lawyers to blindly accept testimony regarding the accuracy of actuarial instruments. ${ }^{145}$ As one state court observes, "[w]e have embarked on the first steps into a new world, arguably a science fiction world, in which judges and juries are asked to prevent crimes years before they occur." ${ }^{146}$ For a judge to make a ruling on

139 Id. (citing Simons, 821 N.E.2d 1184 (Ill. 2004)).

$140 \quad$ Id. at 724

141 United States v. Shields, 597 F. Supp. 2d 224, 236 (D. Mass. 2009), aff'd, 649 F.3d 78 (1st Cir. 2011) ("As is the commonly accepted practice in the field, all three experts in this case used an actuarial tool as part of his evaluation process.").

142 Holtz, 653 N.W.2d at 616 (alteration in original) (citation omitted).

143 Id. at 615 (quoting Johnson v. Knoxville Cmty. Sch. Dist., 570 N.W.2d 633, 637 (Iowa 1997)).

$144 \quad$ See Cailey S. Miller et al., Reliability of Risk Assessment Measures Used in Sexually Violent Predator Proceedings, 24 PSYCHOL. ASSESSMENT 944, 951 (2012).

145 See, e.g., People v. Poe, 88 Cal. Rptr. 2d 437, 440-41 (Ct. App. 1999) (concluding that a Rapid Risk Assessment (RRASOR) score in the above-average risk category, adjusted with appropriate clinical factors, supported a finding that the defendant was likely to engage in sexually violent behavior if released).

Also worth mentioning here is In re Linehan, in which the Minnesota Supreme Court rejected the defendant's argument that the State's expert improperly failed to use actuarial methods, concluding instead that the State's expert relied on base rate recidivism statistics and clinical predictions. 557 N.W.2d 171, 189 (Minn. 1996), cert. granted, vacated on other grounds sub nom. Linehan v. Minnesota, 522 U.S. 1011 (1997). The court also noted testimony that enhanced accuracy may be achieved by combining actuarial methods with clinical judgment. Id. at 177 .

146 Burton, 884 So. 2 d at 1120 (Altenbernd, C.J., concurring). 
the potential future risk of an individual, her ultimate decision is purely based on the subjective opinion of an expert witness, and is devoid of concrete answers or verifiable scientific conclusions. The initial promise of actuarial instruments that would remove the fallibility of the human element and offer quantifiable answers regarding risk to re-offend is understandably enticing. ${ }^{147}$ An opinion responding to a challenge to the admission of Static-99 evidence stated that courts must "respect [the] policy of [the] legislature with respect to the trustworthiness of psychiatric opinion evidence in cases involving sexually dangerous persons."

In a sex offender registration case in a Massachusetts state court, a Static-99 score designating moderate to high risk was used in conjunction with other factors to classify the defendant. ${ }^{149}$ The defendant's expert was qualified to testify but did not utilize the Static-99 in his assessment. ${ }^{150}$ The issued opinion upheld the state's classification level, and found that the state's expert's testimony included the "factors in the so-called Static-99 which provides for a total score" $" 151$ in determining risk to re-offend, and together with the remainder of the admitted evidence, satisfied the Commonwealth's burden of proof. The court addressed the question of whether psychiatrists and psychologists can predict future behavior only by noting that the legislature's admittance of reports and testimony of qualified examiners in SVP hearings demonstrates that this testimony can be reliable, if sometimes imperfect. ${ }^{152}$

Some courts have held that the adversarial protections of cross-examination and rebuttal witnesses would sufficiently allow the defendant the opportunity to challenge actuarial instruments' validity. ${ }^{153}$ This, of course, is only effective if the defendant is afforded an opportunity for a rebuttal witness, and has been assigned effective counsel who is knowledgeable and able to dispute opposing expert witness testimony. ${ }^{154}$

In another instance, an order jointly issued by two Florida trial court judges declared that the actuarial tests were "accepted by a clear majority of the professional community in assessing the risks of recidivism for sexually violent offenders," without a thorough discussion of the

147 See, e.g., People v. Santos, No. 3747/84, 901 N.Y.S.2d 909, at*5 (N.Y. Sup. Ct. Oct. 6, 2009) (“The use of ARAs in predicting sex offender recidivism was an outgrowth of what were seen as the predictive deficiencies of using subjective clinical judgment alone.”).

148 Commonwealth v. Parks, No. 04709, 2005 Mass. Super. LEXIS 225, at*12 (Mass. Super. Ct. Mar. 9 , 2005) (citing Commonwealth v. McGruder, 205 N.E.2d 726, 728 (Mass. 1965)).

149 Parks, 2005 Mass. Super. LEXIS 225, at*5.

$150 \quad I d$. at $* 5-6$.

$151 \quad I d$. at $* 9-10$.

$152 I d$. at $* 12$ ("Judgment must be respected absent a showing that it is utterly without a reasonable foundation or specifically contravenes a Constitutional provision." (citation omitted)).

153 See, e.g., In re Det. of Erbe, 800 N.E.2d 137, 155 (Ill. App. Ct. 2003). See also Halleck v. Coastal Bldg. Maint. Co., 647 N.E.2d 618, 627 (Ill. App. Ct. 1995) (citation omitted) ("On cross-examination, counsel may probe an expert witness' qualifications, experience and sincerity, the weaknesses in the basis of his opinions, the sufficiency of his assumptions, and the general soundness of his opinion.").

154 This issue was explored in In re Linehan, an early case involving an individual committed under Minnesota's SVP law, in which the defendant, represented by competent counsel, challenged his commitment because the state's expert had failed to use actuarial methods in his risk assessment. See 557 N.W.2d at 189. The defendant unsuccessfully argued that by failing to perform actuarial analysis, the state had ignored "state of the art" evidence and the "best available scientific knowledge and methodology." Id. The case was later vacated on other grounds sub nom. Linehan v. Minnesota, 522 U.S. 1011 (1997). 
various tests or a basis for their opinion. ${ }^{155}$ At trial, neither party objected to the judges' description of the "relevant scientific community," even though none of the State's experts could testify about acceptance within the psychiatric community. ${ }^{156}$ On appeal from this case to Florida's appellate court, then-Chief Judge Altenbernd wrote a remarkably thoughtful concurring opinion, specifically discussing the issues related to reliance on unfamiliar actuarial instruments:

I am inclined to believe, however, that the lawyers and trial judges involved in these cases have not yet identified the issues that need to be examined to determine whether these actuarial tests pass the Frye test and whether evidence regarding the tests is more probative than prejudicial. It is not entirely clear to me that the diagnostic method utilized by these experts is generally accepted within the psychiatric and psychological professions, or that the courts should permit opinion testimony based on these methodologies. ${ }^{157}$

Subsequently, he highlighted the difficulties in assessing future risk and questioned whether "humans have the ability to accurately select those people who, by clear and convincing evidence, are likely to engage in future acts of sexual violence if not confined." ${ }^{158} \mathrm{He}$ carefully cautioned that the creation of certain testing instruments were fueled by outside pressures placed on psychiatrists and psychologists to develop a scientific method to uniformly identify dangerous sex offenders, ${ }^{159}$ and clearly noted that although he did "not profess to have the expertise to even phrase all of the questions ... the judiciary needs to obtain the help of those who can ask and answer the necessary questions" before testimony is admitted based on these actuarial instruments. ${ }^{160}$

The opinion rendered by the appeals court in the New Jersey case of In re Commitment of R.S. ${ }^{161}$ lacked the well-reasoned and insightful position offered above, and instead argued that:

Since expert testimony concerning future dangerousness based on clinical judgment alone has been found sufficiently reliable for admission into evidence at criminal trials[, it is] . . logical that testimony based upon a combination of clinical judgment and actuarial instruments is also reliable. Not only does

\footnotetext{
155 Burton, 884 So. 2d at 1118 (Altenbernd, C.J., concurring).

$156 \quad$ Id. at 1118 .

$157 \quad I d$. at 1115

$158 \quad$ Id. at 1116.
}

$159 \quad I d$. at 1118 ("I find it very hard to believe that the membership of the American Psychiatric Association and the membership of the American Psychological Association have reached a consensus that their professions can achieve these predictions with a level of accuracy sufficient to permit the indefinite confinement of an individual."); see also Roeling v. State, 880 So. 2d 1234, 1239 (Fla. Dist. Ct. App. 2004) (defining the "relevant scientific community" that generally accepts these actuarial tests as "licensed clinical psychologists specializing in forensic psychology and the evaluation of sexually violent predators").

160 Burton, 884 So. 2d at 1118 (Altenbernd, C.J., concurring).

161773 A.2d 72 (N.J. Super. Ct. App. Div. 2001). 
actuarial evidence provide the court with additional relevant information, in the view of some, it may even provide a more reliable prediction of recidivism. ${ }^{162}$

An Illinois appellate court similarly concluded that there existed "no logical reason why a professional could not at least consider actuarial instruments, which the profession widely uses and which are less subjective than unaided clinical judgment."163

The problem with this reasoning lies in the understanding of what is "logical." 164 Although logical reasoning is based on earlier or otherwise known statements, events, or conditions, in law, if those "known" statements, events, or conditions are incorrect or false, the logical deduction stemming from those bases is also false. ${ }^{165}$ Philosophically speaking, logic is characterized by clear or valid reasoning that cannot be accomplished without investigation into the basic truths that premise the resulting conclusions. ${ }^{166}$ This issue is presented in the New Jersey case, In re J.P., ${ }^{167}$ which illustrates the court's failure to accurately investigate and understand the complexities and uncertainties of actuarial instruments. The defendant in J.P. joined in the R.S. appeal, but also raised the issue of the appropriateness of using actuarial instruments to assess the future risk of juveniles. ${ }^{168}$ In R.S., the New Jersey appellate court reaffirmed its confidence in the judicial ability to interpret the value and validity of actuarial instruments, noting that "an experienced judge who is well-informed as to the character of the actuarial instruments and who is accustomed to dealing with them is much less likely to be prejudiced by their admission ... [and] accord the appropriate weight to actuarial assessments in any given case, or reject them."169 However, in J.P., the appellate court reversed the trial judge's decision and remanded the case for an evidentiary hearing on the applicability of actuarial instruments to juvenile offenders, ${ }^{170}$ because the trial judge had admitted and relied upon expert testimony utilizing actuarial instruments without hearing any evidence on the valid use of such tools on individuals who committed their offenses while under age eighteen. ${ }^{171}$ The trial judge had adopted, by reference,

$162 I d$. at 90. On appeal, the Supreme Court of New Jersey affirmed the lower court, noting that:

Although there are critics who challenge the validity and predictability of actuarial instruments in sex offender assessments, the record expert testimony and scientific literature demonstrates that clinicians specializing in sex offender assessments generally support the use of actuarial instruments in the overall assessment process even though they do not support reliance on the actuarial instruments alone.

In re R.S., 801 A.2d at 220-221 (citation omitted).

163 In re Det. of Erbe, 800 N.E.2d 137, 155 (Ill. App. Ct. 2003).

164 See generally Mary Massaron Ross, A Basis for Legal Reasoning: Logic on Appeal, 3 J. ASS'N LEGAL WRITING DIRECTORS 177 (2006).

$165 \quad I d$.

$166 I d$.

167772 A.2d 54 (N.J. Super. Ct. App. Div. 2001).

$168 \quad I d$. at 55.

$169 \quad 773$ A.2d at 91.

170772 A.2d at 65 . The appellate court states in their opinion that they doubt any studies or information exists supporting the usage of these tools for juvenile offenders. $I d$. at 61 .

171 Id. at 64 ("The only testimony concerning the application of the instruments to juveniles elicited from 
the prior opinion of the trial judge in R.S.-admitting actuarial instruments as clinical tools in SVPA commitment hearings - and added her own clarification:

They are tools, which are used by clinicians in this area of their expertise. There is nothing that I have ever said nor have I seen anything said by any legal writer that these are anything more than what they purport to be: Actuarial, placing people in groups, matters for consideration by clinicians, not binding. I mean, it's not like an X[-]ray, and I don't think anybody ever said it was. I think it's admissible for what it is. And I'll cast my vote with Judge Freedman on that.

And I'm not going to repeat this exhaustive multi-page-I think he's got sixty pages or more in which he exhaustively goes into the background of these various tests. And I believe that these two [actuarial instruments] are included. Okay. ${ }^{172}$

Confidence in judicial ability cannot be blindly accepted, and even those judges who "have seen it all" should support their decisions with clear and valid reasoning and be held accountable for failing to do proper investigation of the basis underlying their decisions. It is up to effective counsel to ask the necessary questions and request adequate judicial consideration into the propriety of using actuarial tools to evaluate criminal defendants accused of sexually violent crimes.

In In re Williams, the Kansas Supreme Court reviewed the decision of the appellate court, which had overturned a district court finding that the defendant, Mr. Williams, was a sexually violent predator. ${ }^{173}$ The appellate court gave considerable weight to the fact that $\mathrm{Mr}$. Williams's scores on actuarial testing did not exceed a fifty percent risk of sexual re-offending. ${ }^{174}$ Justice Luckert pointed out that there was no authority supporting a particular method of proof, test, or percentage or category of risk. ${ }^{175}$ Ultimately, however, the Kansas court decided that evidence beyond the test scores, based in part on the evaluating clinician's conclusions of risk, could convince a rational fact-finder that the defendant was a sexually violent predator. ${ }^{176}$ Thus, it affirmed the finding of the district court for the State, despite the inconclusiveness of the actuarial tests. $^{177}$

Unfortunately, most courts to date still rely on controverted research ${ }^{178}$ and reveal that

the State's expert at the R.S. evidentiary hearing calls their reliability into question.”).

$\begin{array}{ll}172 & \text { Id. at } 59 . \\ 173 & 253 \text { P.3d } 327,328-29 \text { (Kan. 2011). } \\ 174 & \text { Id. at } 335 . \\ 175 & I d . \\ 176 \quad I d . \text { at } 336 . \\ 177 \quad I d \text { at } 338 . \\ 178 \quad \text { For an overview of the discrepancies in risk assessment, see generally Robin J. Wilson et al., Comparing }\end{array}$ Sexual Offenders at the Regional Treatment Centre (Ontario) and the Florida Civil Commitment Center, 57 INT'L J. OfFENDER THERAPY \& COMP. CRIMINOLOGY 377 (2013); Karen Franklin, Treatment and Risk Among the Most 
the judiciary has failed to ask the necessary questions or demand the necessary answers from the clinical community that would justify civil commitment and the grave deprivation of freedom and liberty based on future risk predictions. ${ }^{179}$

\section{Scientific Reliability: Error Rate and Inherent False Positives}

Actuarial tests are designed to establish or define a small group or sub-population of people in which the risk that a member of the group will commit a violent sexual offense is higher than in the population as a whole. These tests look at whether the likelihood of a particular condition is higher than in the population as a whole, but the pool always contains some people who do not have the particular condition, and thus false identification is inevitable. ${ }^{180} \mathrm{~A}$ false positive occurs when a scientist errs by incorrectly placing a person into a group or category based on a scientific test. ${ }^{181}$ When these tests are utilized in sex offender civil commitment, the result of a false positive is indefinite confinement in a facility that "looks very similar to a prison." ${ }^{\prime 82}$ For instance, one court noted that:

[F]or many purposes, an error rate of $30 \%$ or more is quite acceptable. Life insurance companies, for example, usually charge higher premiums or refuse to insure the pool of obese, cigarette smokers because the probability of a premature death is higher among the members of this pool, even though many members of the pool live to an average age. It is one thing to price insurance based on actuarial device with an error rate of $20 \%$ or higher; it is quite another

Dangerous Sexual Offenders, In THE News: Forensic Psychology, CRIMINOLOGY, AND PsyCHOlOGY-LAW (Feb. 21, 2012), http://forensicpsychologist.blogspot.com/2012/02/treatment-and-risk-among-most-dangerous.html (discussing Wilson et al.'s article). See also Shoba Sreenivasan et al., Alice in Actuarial-Land: Through the Looking Glass of Changing Static-99 Norms, 38 J. AM. ACAD. PSYCHIATRY \& L. 400 (2010); R. Karl Hanson, Who is Dangerous and When are They Safe? Risk Assessment with Sexual Offenders, in Protecting Society From SeXually Dangerous OfFENDERs: LAW, Justice, \& THERAPY 63, 63-72 (Bruce J. Winick \& John Q. La Fond, eds. 2003); In re Registrant G.B., 685 A.2d 1252 (N.J. 1996); In re C.A., 679 A.2d 1153.

179 See, for example, Poe, 88 Cal. Rptr. $2 \mathrm{~d}$ at 440 , in which the court found that a RRASOR score of four, adjusted with appropriate clinical factors, supported a finding that the defendant was likely to engage in sexually violent behavior if released. See also People v. Otto, 95 Cal. Rptr. 2d 236, 241-42 (Cal. Ct. App. 2000), aff'd on other grounds, 26 P.3d 1061 (Cal. 2001) (concluding that a defendant is more likely than not to re-offend, based in part on an expert witness who used results of RRASOR, along with other clinical factors in evidence at an SVP trial).

In Garcetti v. Superior Court, the court held that the Static-99, "a psychological instrument that uses an actuarial method to produce a profile of a person's likelihood of re-offense with an accuracy rate of over 70 percent, and that is supplemented or adjusted by use of clinical factors, can form the basis for an expert opinion on future dangerousness.” 102 Cal. Rptr. 2d at 238-239.

180 Janus \& Prentky, supra note 94 at 1464-65.

181 Hamilton, supra note 104, at 749 (noting that a common problem is "improper interpretation that groupbased scores provide risk-assessment estimates that are individualized to specific defendants"). See, e.g., Rosado, 889 N.Y.S.2d at 379-380 ("Actuarial instruments do not measure psychological constructs such as personality or intelligence. In fact, they do not measure any personal attributes of the particular sex offender at all. Rather, they are simply actuarial tables - methods of organizing and interpreting historical data." (quoting In re R.S., 773 A.2d at 92)).

Burton, 884 So. 2d at 1120 (Altenbernd, C.J., concurring). 
to deprive citizens of their constitutional liberty based on actuarial devices with such high error rates. ${ }^{183}$

However, courts continue to use actuarial tests in sex offender civil commitment cases. For example, one court opinion incorrectly interpreted the results of the Static-99 and noted that it "calculated defendant's risk of re-offense." 184 In another case, an expert testified that the defendant's score of seven on Static-99 "means that the likelihood of [the defendant] being convicted of a new sex offense is $39 \%$ within five years of being released ...."185 Experts have also mischaracterized the use of multiple actuarial tools when such tools are relatively consistent in the direction of their risk predictions, presuming that similar results from numerous tools strengthen the reliability of each individual tool. ${ }^{186}$ The known margin of error of the Static-99 has even been relied upon to undermine an expert's diagnosis of a defendant using the Static$99 .{ }^{187}$

The New Jersey case of In re R.S. reflects the dissension amongst experts in the reliability and accuracy of actuarial assessment tools. ${ }^{188}$ In that case, the State's experts testified in favor of the use of actuarial instruments alluding to "an 'overwhelmingly' large number of research studies [that] support the use of static factors over the use of dynamic factors for making sex offender risk determinations," 189 even though all the experts admitted that none of the studies had been peer-reviewed. ${ }^{190}$ The experts for the defense found the instruments to be generally unreliable in assessing risk. One expert noted that psychologists have a history of utilizing invalid instruments, and that actuarial tools are lacking in

psychometric reliability (If the test is administered to the same person on more than one occasion, are the results consistent?), inter-rater reliability (If two different individuals administer the test, are the same results achieved?), and

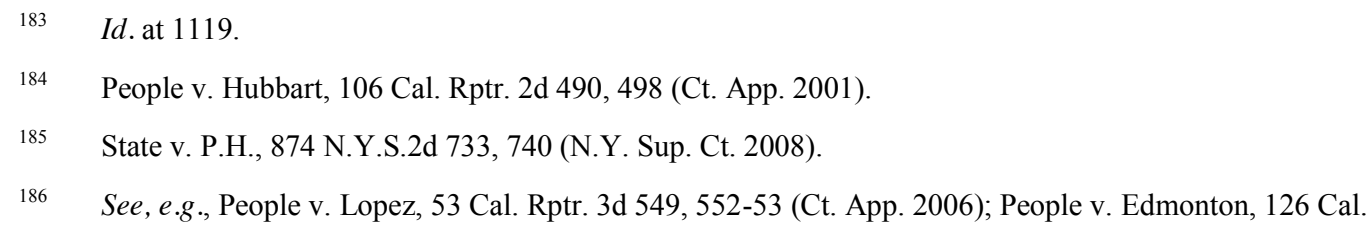

187 See People v. McKee, 73 Cal. Rptr. 3d 661, 688 n.23, 689 (Ct. App. 2008), aff'd in part, rev'd in part on other grounds, 223 P.3d 566 (Cal. 2010) (relying on expert's belief that defendant would re-offend even though the expert observed that the defendant's Static-99 score was lower than other SVPs, and concluded that he was not diagnosed properly).

188 Hamilton, supra note 104, at 752-753 (noting discrepancies in the scoring of defendants, both between experts on competing sides and between two or more experts on the same side, which courts have generally treated as issues of fact that are not impacted by the courts' reliance on these instruments and their scoring rules).

189 In re R.S., 773 A.2d at 79 . The argument as to interpretation of risk fell upon semantics, with one of the State's experts acknowledging that it "is a misuse of the instruments to say that a person with a certain score has a specific risk of recidivism. Rather, it is proper to say that a person with a certain score is in a group that has been shown through research to have a specific risk of recidivism." Id. at 81 .

190

Id. at 79 . 
scale consistency[.] (Are the items on the same scale internally consistent? Do they measure the same thing?). ${ }^{191}$

The New Jersey appellate court concluded that authoritative scientific and legal writings, along with the existence of numerous workshops held nationwide on the subject of risk assessment, established that actuarial instruments were "an accepted and advancing method of helping to assess the risk of recidivism among sex offenders." ${ }^{192}$ As the Appellate Division summarized:

The extensive expert testimony in this matter concerning validation studies, cross-validation studies, reliability studies, correlation coefficients, and clinically-derived factors attests to reliability in this context, where the actuarials [sic] are not used as the sole or free-standing determinants for civil commitment. They are not litmus tests. There is no requirement that the actuarial instruments be the best methods which could ever be devised to determine risk of recidivism. What is required is that they produce results which are reasonably reliable for their intended purpose. ${ }^{193}$

The results from these actuarial tests tend to be used by courts to bolster the opinion that the individual is dangerous and should be indefinitely committed, ${ }^{194}$ which begs the crucial question not often asked or answered: what is their intended purpose?

\section{Jury Taint}

Concern over jury confusion has elicited a number of objections to the usage of actuarial instruments to determine risk in sexual offender civil commitment cases, although these objections have occasionally been struck down. ${ }^{195}$ In two cases, however, courts have excluded such expert testimony, one after finding that "the Static-99 does not distinguish between, nor can it explain, the reasons why a person might re-offend," 196 and another after finding testimony

$\begin{array}{ll}191 & I d . \text { at } 81 . \\ 192 & I d . \text { at } 95 . \\ 193 & I d . \text { at } 91 .\end{array}$

194 See Hamilton, supra note 104, at 750 ("While courts have tended to accept the individualized statistic when the actuarial-based risk estimate is high, they have tended to highlight the group-based nature of actuarial scores when the results are low."), citing In re Civil Commitment of K.S., No. SVP-344-03, 2008 WL 631284, at *3-4 (N.J. Super. Ct. App. Div. Mar. 11, 2008) (noting "high risk" score on Static-99 as part of determination that commitment was proper); State v. Vanek, No. 89125, 2007 WL 4126660, at *3 (Ohio Ct. App. Nov. 21, 2007) (finding for state despite low score while noting that "the utility of the Static-99 evaluation as a diagnostic tool for individual risk assessment is open to question" (citation omitted)); State v. Ellison, No. 78256, 2002 WL 1821927, at *2, 7 (Ohio Ct. App. 2002) (holding that court need not give much weight to Static-99 evidence showing defendant to be "low-to-medium risk," since actuarialbased risk estimates could "be at odds with Ohio's statutory scheme" requiring individualized determinations).

195 See, e.g., Ward, 83 Cal. Rptr. 2d at 831 ("Frye applies to cases involving novel devices or processes, not to expert medical testimony, such as a psychiatrist's prediction of future dangerousness or a diagnosis of mental illness.”).

State v. Rosado, 889 N.Y.S.2d 369, 391-92 (Sup. Ct. 2009). 
based on the SVR-20 test inadmissible under Frye. ${ }^{197}$ In People v. Santos, ${ }^{198}$ a New York court opined that risk assessment "is a dynamic and ever changing discipline, where new research findings continually modify the understanding of risk." 199 The court focused on the recent revision of the Static-99, "the most common ARA in use throughout the world today," "200 to exemplify the changing opinions on risk, and notably the fact that recidivism rates for sex offenders are significantly lower than when the original norms were compiled in $2003 .{ }^{201}$

In 2002, Iowa faced its first appellate challenge to the admissibility of expert testimony regarding actuarial risk assessment instruments. ${ }^{202}$ The appellate court admitted testimony based on the scoring of actuarial instruments - including the Rapid Risk Assessment for Sex Offender Recidivism ("RRASOR"), the Static-99, the Minnesota Sex Offender Screening Tools ("MnSOST"), and the Minnesota Sex Offender Screening Tools-Revised ("MnSOST-R")—-some of which had only been in existence for two to three years. ${ }^{203}$ The court stated that the expert's reliance on these instruments was appropriate since the expert had also conducted a full clinical evaluation, including thorough review of a comprehensive file of materials and documents relating to the defendant's past criminal history. ${ }^{204}$ The defendant's expert, arguing against actuarial instruments, told the district court that although it is acceptable to perform the tests:

What's not accepted at this point in time is adding up those numbers to get some kind of a score that you can then change into a prediction of the future. That's where the science doesn't support things. So having a list of bad signs, that's perfectly acceptable. Changing them into a number to predict the future, there's no basis for that. And if one wants to use the tests, one has to acknowledge that there is no foundation for that. ${ }^{205}$

Disregarding the cautionary testimony on the usage of these instruments, the trial court found the instruments to be reliable, and the judge was confident that the jury would not be "left with a mistaken assumption that [the testimony of the actuarial instruments would be] . . all they need to look at." 206

The Iowa appellate court affirmed the lower court's decision. ${ }^{207}$ The court rejected the argument that cross-examination on the statistical and methodological problems associated with

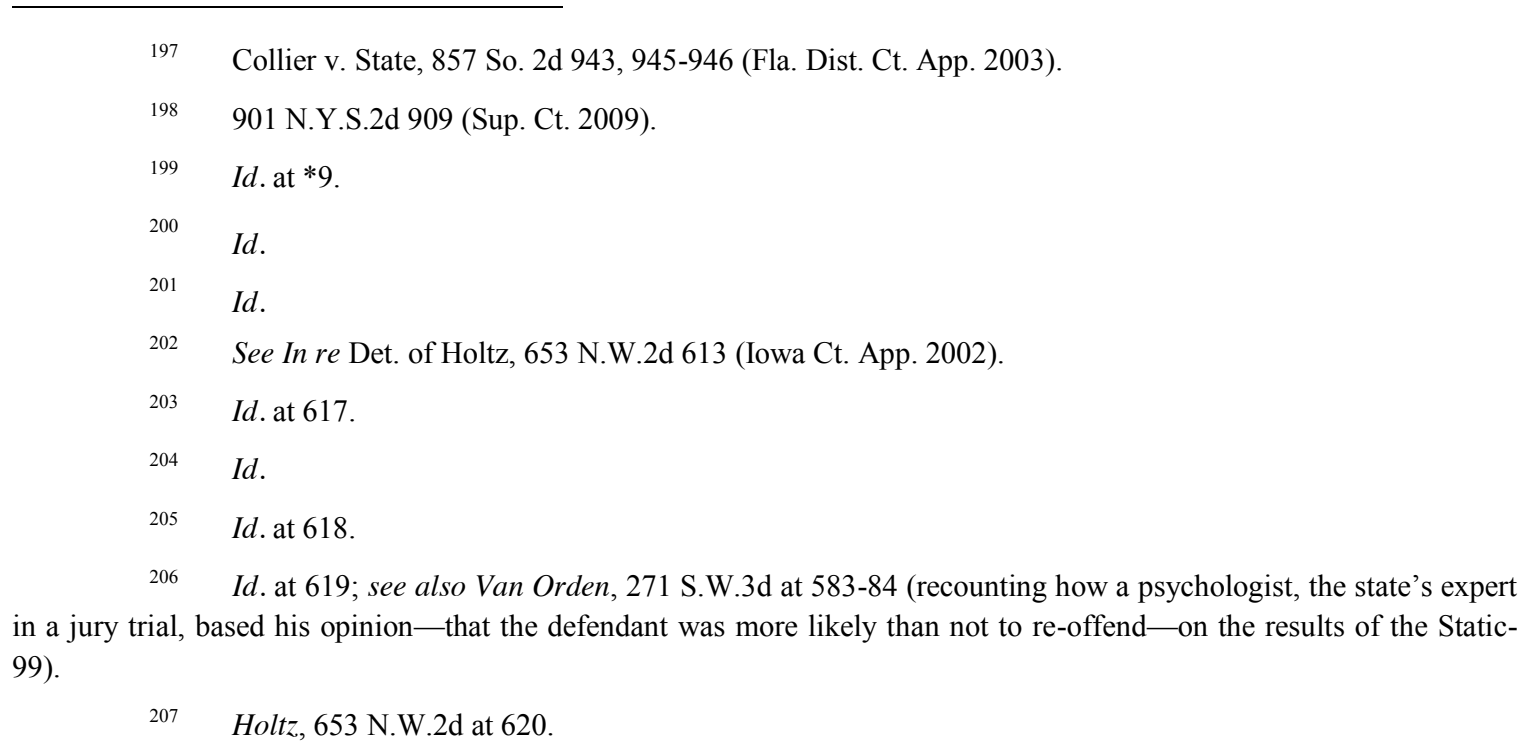


actuarial instruments would confuse and mislead the jury. ${ }^{208}$ Further, the court cited to the thenrecent conclusion of the New Jersey Superior Court ${ }^{209}$ that "[o]ur research has revealed no state appellate court decision which has found actuarial instruments inadmissible at SVP proceedings." 210

One individual facing civil commitment argued before the court that Static-99 may confuse a jury because the actuarial instrument ${ }^{211}$ only predicts group risk, which cannot always be accurately applied to individual risk. ${ }^{212}$ At least one court has found that results of the Static-99 were admissible as testimony in cases involving the civil commitment of a sexually violent predator so long as the instrument was used in conjunction with a full clinical evaluation. ${ }^{213}$

As explained in People v. McDonald ${ }^{214}$ :

When a witness gives his personal opinion on the stand - even if he qualifies as an expert-the jurors may temper their acceptance of his testimony with a healthy skepticism born of their knowledge that all human beings are fallible. But the opposite may be true when the evidence is produced by a machine: like many laypersons, jurors tend to ascribe an inordinately high degree of certainty to proof derived from an apparently "scientific" mechanism, instrument, or procedure. Yet the aura of infallibility that often surrounds such evidence may well conceal the fact that it remains experimental and tentative. For this reason, courts have invoked the Kelly-Frye rule primarily in cases involving novel devices or processes such as lie detectors, "truth serum," Nalline testing,

208 Id. at 619-20 (“[The instruments'] limitations were clearly made known to the jury.”).

$209 \quad$ In re R.S., 773 A.2d at 96.

$210 I d$. at 619 (quoting In re R.S., 773 A.2d at 96). In footnote 5 of the Holtz opinion, the Iowa court also cited a number of cases in which evidence based on actuarial instruments had been admitted, including Strauss, 20 P.3d at 1026 (upholding use of MnSOST, RRASOR and VRAG); Garcetti, 102 Cal. Rptr. 2d at 241 (allowing use of PCL-R, RRASOR and Static-99); In re Det. of Walker, 731 N.E.2d 994, 998, 1003 (Ill. App. Ct. 2000) (upholding use of RRASOR); Campbell, 986 P.2d at 779 (upholding use of actuarial instruments and noting that proper weight of evidence is question for jury); Poe, 88 Cal. Rptr. 2d at 440 (upholding use of RRASOR); Ward, 83 Cal. Rptr. 2d at 832 ("In civil commitment cases, where the trier of fact is required by statute to determine whether a person is dangerous or likely to be dangerous, expert prediction may be the only evidence available.”).

See also Romley, 35 P.3d at 89 (concluding that the "use of actuarial models by mental health experts to help predict person's likelihood of recidivism is not the kind of novel scientific evidence or process to which Frye applies"); Commonwealth v. Reese, No. CIV.A 00-0181-B, 2001 WL 359954, at *9 (Mass. Super. Ct. 2001) (noting that "statistics, in general, are better predictors of future sexual dangerousness than clinical judgments"), vacated, 781 N.E.2d 1225 (Mass. 2003).

Many of the aforementioned cases within this footnote are cited in Holtz, 653 N.W.2d at 619 n.5.

211 Rebecca L. Jackson \& Derek T. Hess, Evaluation for Civil Commitment of Sex Offenders: A Survey of Experts, 19 SEXUAL ABUSE 425, 427-28 (2007).

$212 \quad$ Van Orden, 271 S.W.3d at 587.

213 See In re Care and Treatment of Murrell, 215 S.W.3d 96, 112 (Mo. 2007) (en banc) (acknowledging an argument that actuarial instruments should be rejected as "irrelevant" because "they are a product of the recidivism of the test group, not the individual being evaluated").

214690 P.2d 709, 724 (Cal. 1984) (en banc), overruled on other grounds by People v. Mendoza, 4 P.3d 265

(Cal. 2000). 
experimental systems of blood typing, "voiceprints," identification by human bite marks, microscopic analysis of gunshot residue, and hypnosis and, most recently, proof of guilt by "rape trauma syndrome." In some instances the evidence passed the Kelly-Frye test, in others it failed; but in all such cases "the rule serves its salutary purpose of preventing the jury from being misled by unproven and ultimately unsound scientific methods."215

How competent is a jury to accurately discern testimony about the results of the Static-99 test? In a 2003 case, California presented the testimony of two psychologists who performed the Static-99 test during their evaluations. ${ }^{216}$ The first expert found that the Static-99 test indicated a fifty-two percent chance that defendant would re-offend within fifteen years. ${ }^{217}$ The second psychologist testified that she used the Static-99 test to get a "general thumbnail estimate of where [she] thought [defendant] would fall," but did not rely on the test. ${ }^{218}$ One psychologist admitted that the developer of the Static-99 continually revises the instrument; thus, it was not perfect and no study had shown that adjusting the actuarial risk assessment would produce a more accurate measure of risk. ${ }^{219}$ The expert also explained that psychologists do not have actuarial instruments that encompass all the known risk factors obtained from research on re-offenders. ${ }^{220}$ The defendant's psychologist testified that "the Static-99 test is a work-in-progress and its reliability is unknown. ... [T] he factors considered in the Static-99 test are important and must be considered, but [the expert] objected to using the assessment as an arithmetic personality profile." ${ }^{221}$ He pronounced that defendant's behavior was "opportunistic, not predatory, and that defendant had control over his behavior." 222 Both state experts found that the defendant posed a substantial risk of re-offense. ${ }^{223}$

The California appellate court upheld the commitment based on the information that the state's experts relied on other factors outside of the actuarial instruments to make their assessment, and held that the lower court had adequately informed the jury that the procedures used in the Static-99 were objective and fallible. ${ }^{224}$ The court felt confident in its assumption that no reasonable juror would mistake either expert's use of the Static-99 test as a source of infallible truth on the issue of defendant's risk of re-offending. ${ }^{225}$ Of course, where there is a dispute

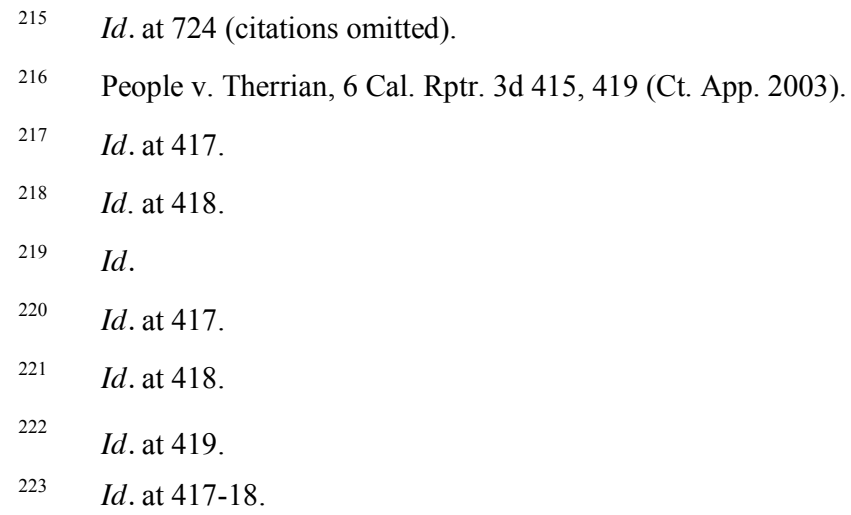

$224 I d$. at 420 ("No precise legal rules dictate the proper basis for an expert's journey into a patient's mind to make judgments about his behavior. Psychological evaluation is a learned professional art, rather than the purported exact 'science' with which Kelly/Frye is concerned." (citing People v. Stoll, 783 P.2d 698 (Cal. 1989) (internal citations omitted))). 
between clinicians, the fact-finder is left with a simple credibility judgment, in which the fear of sexual violence creates a strong bias in favor of assessments that are more protective of public safety. ${ }^{226}$ This becomes especially problematic in light of valid and reliable evidence that juries are "more likely to undervalue, rather than overvalue, statistical evidence." 227

In the New Jersey case of R.S., the trial judge acknowledged that unreliable psychological testimony might mislead a jury but concluded that, where the court is the trier of fact, the risk of confusion from expert testimony is greatly diminished. ${ }^{228}$ Similarly, a Florida judge questioned whether jurors should be called upon to evaluate the validity of these tests when deciding issues of liberty, noting that " $[\mathrm{w}]$ hen presented to a jury, these tests, coupled with the testimony of the experts who rely on them, may imply an infallibility not found in pure opinion testimony." 229 In a recent experimental study, Professors Nicholas Scurich and Daniel Kraus concluded that adjusting actuarial risk with clinical judgment was taken into consideration by mock jurors only when it increased the risk estimate, not when it diminished it. ${ }^{230}$

Jury taint is most definitely compounded by a judge or lawyer's blind acceptance or unfamiliarity with the tools and tests. A jury's susceptibility to a judge's confidence in actuarial tools or a heavily-weighted, one-sided interpretation of the tools' reliability is a valid concern, and may seal a defendant's lifetime commitment.

\section{B. Expert Qualifications}

The debate over the necessary expert qualifications required to testify in a sexual offender commitment case has been frequently argued. ${ }^{231}$ One Texas trial court found, after conducting a Daubert hearing, that the defendant's expert lacked the requisite forensic training and experience to testify on his behalf. ${ }^{232}$ On appeal, the defendant argued that the trial court abused its discretion and denied him a fair trial when it excluded the testimony of his only expert-despite her documented extensive experience and training in providing sex offender treatment - and prevented him from presenting his side of the case to the jury. ${ }^{233}$ The State

MMPI as source of infallible truth on personality, predisposition or criminal guilt” (citing Stoll, 783 P.2d 698)).

226 Janus \& Prentky, supra note 94, at 1448.

227 Id. at 1451 (citing, inter alia, Brian C. Smith et al., Jurors' Use of Probabilistic Evidence, 20 LAW \& HUM. BEHAV. 49, 51 (1996)).

$228 \quad$ In re R.S., 773 A.2d at 85.

229 Burton, 884 So. 2 d at 1117 (Altenbernd, C.J., concurring) (internal quotations omitted) (citing Flanagan v. State, 625 So. 2d 827 (Fla. 1993)).

230 Nicholas Scurich \& Daniel A. Krauss, The Effect of Adjusted Actuarial Risk Assessment on MockJurors' Decisions in a Sexual Predator Commitment Proceeding, 53 JuRIMETRICs J, 395 (2013). But see Marcus T. Boccaccini et al, Do Scores from Risk Measures Matter to Jurors? 19 PSYCHOL. PUB. POL'Y \& L. 259, 260 (2013) ("[J]urors asked to make decisions in SVP cases are more likely to be influenced by testimony based on clinical judgment than by testimony based on findings from risk-assessment instruments.").

231 Ward, 83 Cal. Rptr. 2d at 832 ("Whether [the experts] used clinical or actuarial models and whether they specifically followed the DMH handbook are not reasons to exclude their testimony. Even if a difference of opinion exists among professionals on these matters, the experts were not restricted to one methodology or another.").

232 In re Commitment of Bohannan, 379 S.W.3d 293, 297-298 (Tex. Ct. App. 2010).

$233 \quad$ Id. at 300. 
maintained that any error in excluding the defendant's expert was harmless, despite that her opinion stated that the defendant lacked a behavioral abnormality "at this time." ${ }^{234}$ The appellate court overturned the trial court's ruling and concluded that the defendant's expert was qualified to testify to the likelihood of re-offense, "a critical issue disputed by the parties, and without her testimony, the jury had only the State's experts to guide them in determining one of the critical issues in the case." 235

On subsequent appeal, the Texas Supreme Court issued a number of findings regarding the issue of expert qualifications, in concluding that the trial court abused its discretion in excluding the defendant's expert. First, it held that "the [Texas SVP] Act does not prescribe the qualifications for experts to testify whether a person has the behavioral abnormality required for an SVP ... [and] in the Legislature's view, an expert used to assess whether a person is an SVP is not constitutionally required to be a physician." 236 Second, "credentials are important, but credentials alone do not qualify an expert to testify... [and] a medical license does not automatically qualify the holder to testify as an expert on every medical question." 237 Third, "trial courts must ensure that those who purport to be experts truly have expertise concerning the actual subject about which they are offering an opinion." "238 Specifically, "[t]he test is whether the offering party has established that the expert has knowledge, skill, experience, training, or education regarding the specific issue before the court which would qualify the expert to give an opinion on that particular subject." 239 Fourth, "opinions about behavior... and psychology depend largely on the subjective interpretation of the expert,' and opinions 'too dependent upon [an expert's] subjective guesswork' must be excluded." 440 "The expert's experience, knowledge, and training are crucial in determining whether the expert's opinions are admissible." ${ }^{241}$ Finally, the court pointed out that "risk assessments are to a degree subjective, and in evaluating an expert's qualifications to make them, it is important to know what training and experience an expert has in minimizing that subjectivity." 242

A final concern stems from the quality and extent of training that is sought and available to experts utilizing these tools. The authors of the Static-99 write in their coding rules that they "strongly recommend training in the use of the Static-99 before attempting risk assessments that may affect human lives." 243 In the initial trials involving actuarial instruments, formal training manuals for the instruments did not exist. Only articles, technical instructions, varied workshops by the instruments developers ${ }^{244}$ and materials on the Internet ${ }^{245}$ were available to aid evaluators 
in scoring.

An expert in Illinois scored three actuarial risk assessment instruments after receiving about 150 hours of specialized training geared to the proceedings under the state's SVP Act, including the administration of actuarial risk assessment instruments and other evaluation tools. Based on those scores, the expert placed the defendant in "membership with a group of sex offenders who did sexually re-offend at a fairly high rate." 246

In another instance, the Kansas Supreme Court upheld commitment even though the state's expert had performed only seventeen or eighteen prior sexual predator evaluations. ${ }^{247}$ The court reinstated the order of commitment:

If we were weighing the evidence and assessing credibility, we might reach a different result from that of the district court. But that is not our role and should not have been the role of the Court of Appeals. Rather, we look at all of the evidence in the light most favorable to the State to determine if a reasonable fact finder would find the State had met its burden.

As is often true in cases such as this, the dispute became a battle of the
experts.

\section{Counsel's Responsibilities}

These complex issues and circumstances must be considered in evaluating the quality of representation afforded to individuals in potential sexual predator commitment cases. These cases are truly like no other in the justice system and require a heightened standard of representation. To meet this heightened standard, counsel must use every resource and tool at his disposal to be effective and offer ethical and rigorous representation.

Counsel must seek out and have access to expert instruction and opinion on the psychiatric, social, and political elements of each case-skills that are most likely beyond most attorneys' schooling and legal education. Without such access, counsel has little hope of understanding the opinions and expertise that he will confront throughout the development of the case, and may be likely to provide inadequate representation. Only through stricter standards of representation will we have the ability, in the words of a Florida appellate court, to "honor and

\footnotetext{
244 Hamilton, supra note 104, at 733 ("There are no criteria, however, for the scope, time, or regimen for training or otherwise certifying potential assessors on the actuarial instruments.").

245 Id. at 733 ("Mostly, information is vicariously available on the internet and through occasional training classes.").

$246 \quad$ In re Det. of Erbe, 800 N.E.2d 137, 144 (Ill. App. Ct. 2003).

247 In re Williams, 253 P.3d 327, 329 (Kan. 2011).

248 Williams, 253 P.3d at 338. In arguing before the Kansas Supreme Court, the State argued that the Court of Appeals focused on the statistical data from the risk assessment tools finding that the percentages of risk, generated by the actuarial tests, were "rather low in comparison to other defendants who have been found to be sexually violent predators." Id. at 335; the lower court proceedings (which were later reversed) can be found at In re Williams, 2009 WL 2762455 (Kan. Ct. App. 2009).
} 
trust the heritage of freedom and liberty that has made this country strong."249

\section{APPOINTMENT OF EXPERTS}

\section{A. The Defendant's Right to an Expert: Ake v. Oklahoma}

Nearly thirty years ago, the U.S. Supreme Court addressed the question of a defendant's right to an expert in a criminal trial. ${ }^{250}$

In Ake v. Oklahoma, ${ }^{251}$ a death penalty case, the Supreme Court ruled that an indigent criminal defendant who makes a threshold showing that insanity is likely to be a significant factor at trial is constitutionally entitled to a psychiatrist's assistance. The Court observed that it had "long recognized that when a State brings its judicial power to bear on an indigent defendant in a criminal proceeding, it must take steps to insure that the defendant has a fair opportunity to present his defense." This principle, grounded in the due process clause's guarantee of "fundamental fairness," derives from the belief "that justice cannot be equal when, simply as a result of his poverty, a defendant is denied the opportunity to participate meaningfully in a judicial proceeding in which his liberty is at stake." 252

"Meaningful access to justice" is the theme of the relevant cases, the Court found, noting that "mere access to the courthouse doors does not by itself assure a proper functioning of the adversary process." A criminal trial is "fundamentally unfair if the State proceeds against an indigent defendant without making certain that he has access to the raw materials integral to the building of an effective defense." 253

... [The Court] considered the "pivotal role" psychiatry has come to play in criminal proceedings, reflecting the "reality ... that when the State has made the defendant's mental condition relevant to his criminal culpability and to the

Burton, 884 So. $2 \mathrm{~d}$ at 1121 (Altenbernd, C.J., concurring).

250 One of the authors of this Article, MLP, also discussed this case in Michael L. Perlin, "And I See Through Your Brain": Access to Experts, Competency to Consent, and the Impact of Antipsychotic Medications in Neuroimaging Cases in the Criminal Trial Process, 2009 STAN. TECH. L. REV. 4 (2009). This Part contains several excerpts from that article, from which citations have been omitted.

251470 U.S. $68,74(1985)$.

252 Perlin, supra note 250 (citations omitted).

253 Id.; see Perlin, supra note 250, at n.49 ("While such a defendant does not have a right to all the assistance that a wealthier defendant might be able to purchase, he is nonetheless entitled to 'an adequate opportunity to present [his] claims fairly within the adversary system.”') (quoting Ross v. Moffitt, 417 U.S. 600, 612 (1974)).
} 
punishment he might suffer, the assistance of a psychiatrist may well be crucial to the defendant's ability to marshal his defense."254

The Court set out what it perceived as the role of the psychiatrist in such cases ${ }^{255}$ :

$[\mathrm{P}]$ sychiatrists gather facts, both through professional examination, interviews, and elsewhere, that they will share with the judge or jury; they analyze the information gathered and from it draw plausible conclusions about the defendant's mental condition, and about the effects of any disorder on behavior; and they offer opinions about how the defendant's mental condition might have affected his behavior at the time in question. They know the probative questions to ask of the opposing party's psychiatrists and how to interpret their answers. Unlike lay witnesses, who can merely describe symptoms they believe might be relevant to the defendant's mental state, psychiatrists can identify the "elusive and often deceptive" symptoms of insanity, ... and tell the jury why their observations are relevant. Further, where permitted by evidentiary rules, psychiatrists can translate a medical diagnosis into language that will assist the trier of fact, and therefore offer evidence in a form that has meaning for the task at hand. Through this process of investigation, interpretation, and testimony, psychiatrists ideally assist lay jurors, who generally have no training in psychiatric matters, to make a sensible and educated determination about the medical condition of the defendant at the time of the offense. ${ }^{256}$

Importantly, for purposes of the question we are facing here,

[t]he courts have generally read Ake narrowly, and have refused to require appointment of an expert unless it is "absolutely essential to the defense." By way of examples, courts have split on whether there is a right to an expert psychologist to perform psychological testing under Ake, and have also, without citing Ake, rejected an application for the right to the appointment of a social psychologist to aid in jury selection. Ake, on the other hand, was relied on so as to require the appointment of a pathologist in a criminal case. On the perhaps-closer question of the requirement of the appointment of a DNA expert, after an intermediate appellate court in Virginia relied on Ake to require the appointment of such an expert, that decision was subsequently vacated, with no discussion of Ake in the subsequent opinion. ${ }^{257}$

The application of Ake to SVP proceedings remains an open question. ${ }^{258}$ As the Crane

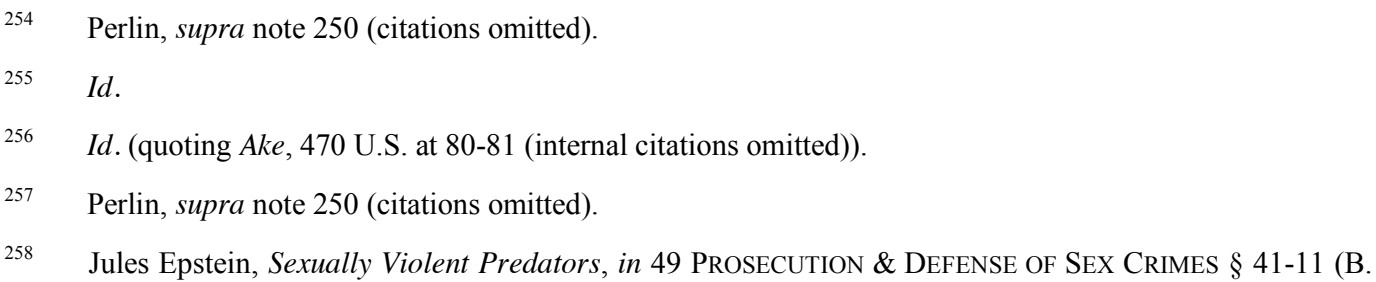


court noted, the "science of psychiatry, which informs but does not control ultimate legal determinations, is an ever-advancing science, whose distinctions do not seek precisely to mirror those of the law." 259 It would therefore seem necessary to provide individuals facing SVP civil commitment with an absolute right to the appointment of an expert witness. Perhaps courts may follow the lead of the pre-Ake case, Little v. Streater, ${ }^{260}$ which conferred a right to state-funded blood testing in paternity actions because of their "quasi-criminal status." ${ }^{261}$ A Texas appellate court, citing Little, ruled that "[b]ecause the SVP statute provides for assistance of counsel, due process requires a person to be able to enjoy that protected right." ${ }^{262}$ Without concluding whether the SVPA was civil or quasi-criminal, the same court held that the defendant's liberty interests, including the statutory right to counsel, were violated. ${ }^{263}$ The court distinguished Allen v. Illinois because it involved "actual treatment in a psychiatric hospital." 264 However, the Texas Supreme Court reversed the ruling of the appellate court and reiterated that competency hearings are not required for civil proceedings, ${ }^{265}$ noting that by their very nature, civil commitments often involve individuals who would be incompetent to stand trial. ${ }^{266}$ Criminal due process rights would only apply if the individual were to violate the terms of his civil commitment by committing a felony. ${ }^{267}$ Although the Texas Supreme Court sidestepped the right-to-counsel issue, the court's decision makes it even more necessary to have legislative standards requiring the appointment of a qualified mental health expert.

Without mention of any right to an expert witness, one Florida court found that to meaningfully exercise due process rights, a SVPA respondent must be competent so that she may both testify on her own behalf and assist counsel in challenging the alleged facts. ${ }^{268}$ The court stressed that any inability to assist counsel in challenging the facts presented at trial violates due

Anthony Morosco ed., 2007).

259 Kansas v. Crane, 534 U.S. 407, 413 (2002) (citing Ake, 470 U.S. at 81, for the proposition that "psychiatry [is] not 'an exact science"”).

$\begin{array}{ll}260 & 452 \text { U.S. } 1 \text { (1981). } \\ 261 & \text { Id. at } 9-10 . \\ 262 & \text { Commitment of Fisher v. State, } 123 \text { S.W.3d 828, } 838 \text { (Tex. Ct. App. 2003) (en banc), rev'd, } 164 \text { S.W.3d }\end{array}$ 637 (Tex. 2005) (citing Little v. Streater, 452 U.S. 1, 16 (1981)) ("[A] statute . . may be held constitutionally invalid as applied when it operates to deprive an individual of a protected right although its general validity as a measure enacted in the legitimate exercise of state power is beyond question.").

$263 I d$. at 838 ("[The defendant's] due process rights were violated because competent evidence indicated his incapacity both to participate in the proceeding in an effective way and his demonstrated inability to factually or rationally utilize his right to counsel.").

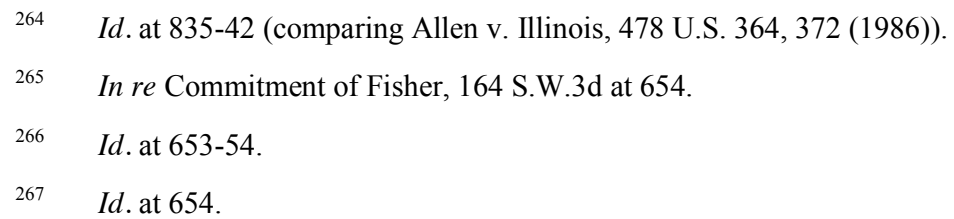

In 2003, the Texas Legislature revised the SVPA to allow a court to appoint outside counsel for alleged SVPs if no representative of the Office of the State Counsel for Offenders is available.

See TeX. Health \& SAFety Code AnN. § 841.005(b) (West 2013) (effective Sept. 1, 2003).

268 In re Commitment of Branch, 890 So. 2d 322, 327 (Fla. Dist. Ct. App. 2004). 
process, and the right is simply illusory. ${ }^{269}$

Nevertheless, other courts have come out differently. Although one Pennsylvania appellate court found a right to court-funded expert assistance for an SVP defendant, ${ }^{270}$ and while one Florida appellate court has applied Ake in a similar context, ${ }^{271}$ it appears that only four states statutorily provide access to experts in such cases, ${ }^{272}$ and in at least one of those states, the constitutional argument has been rejected. ${ }^{273}$ California's SVPA expressly authorizes the appointment of experts for indigent litigants, ${ }^{274}$ but the state does not have to give an indigent defendant a confidential evaluation from a non-testifying expert. ${ }^{275}$ Citing Ake, one California appellate court explained, "there is no right to more than one appointed mental health expert and no right to a favorable evaluation." 276 This is even more problematic when we recognize that valid and reliable research indicates that even mental health clinicians may lack formal training in risk assessment, and thus may be unaware of risk assessment research findings. ${ }^{277}$

A recent article has considered the application of Ake to cases involving children's deaths - a cohort of cases that would certainly inspire some of the same enmity as is found in SVPA cases. ${ }^{278}$ The article has argued that, given "courts' ready admission of prosecutorial forensic evidence that may be invalid, unreliable, or misleading and the defendant's lack of a fair opportunity to rebut such evidence," ${ }^{279}$ Ake should apply in such cases. Certainly, identical arguments could be made for SVPA cases.

269 Id. (emphasizing "that it is not the admission of hearsay that thwarts a [Florida SVPA] respondent's due process rights .... [i]nstead, it is an incompetent respondent's inability to assist counsel in challenging the facts contained in those hearsay statements that violates due process").

$270 \quad$ See Curnutte, 871 A.2d at 842-44.

271 See Lavender v. State, 889 So. 2d 882, 885 (Fla. Dist. Ct. App. 2004).

272 See Epstein, supra note 258, § 41.02 (stating that Arizona, California, Kansas, and Washington have laws that provide expert assistance to indigent defendants).

See also In re Detention of Kortte, which held that (1) if the sex offender who is the subject of proceedings under the Illinois SVPA is indigent, he is entitled as matter of due process to the appointment of an expert; (2) if a sex offender who is the subject of proceedings under the Illinois SVPA does not submit to an evaluation by an expert from the state's Department of Human Services, but the state still calls an examining expert, due process requires that the offender be permitted to call an examining expert of his own; and (3) if the state calls only non-examining experts, the sex offender must be permitted to call one as well. 738 N.E.2d 983, 988 (Ill. App. Ct. 2000).

273 People v. Angulo, 30 Cal. Rptr.3d 189, 198, 202 (Cal. Ct. App. 2005) (holding that statutorilyauthorized expert evaluative reports of defendants may not be privileged).

274 CAL. WELF. \& INST. CODE $§$ 6603(a) (West 2014) ("In the case of a person who is indigent, the court shall appoint counsel to assist him or her, and, upon the person's request, assist the person in obtaining an expert or professional person to perform an examination or participate in the trial on the person's behalf.").

$275 \quad$ Angulo, 30 Cal. Rptr. 3d at 197.

$276 \quad I d$.

277 Janus \& Prentky, supra note 94, at 1495 (citing, inter alia, Eric B. Elbogen et al., Perceived Relevance of Factors for Violence Risk Assessment: A Survey of Clinicians, 1 InT'L J. ForensiC MENTAL HEALTH 37, 44 (2002)).

278 Laurel Gilbert, Sharpening the Tools of an Adequate Defense: Providing for the Appointment of Experts for Indigent Defendants in Child Death Cases under Ake v. Oklahoma, 50 SAN DIEGO L. REV. 469, 475 (2013).

279

Id. 


\section{B. Despised Populations}

Sex offenders ${ }^{280}$ are in the media and legal spotlight, and are considered to be the most despised segment of the American population. ${ }^{281}$ Regularly reviled as "monsters" by district attorneys in jury summations, ${ }^{282}$ judges at sentencing, ${ }^{283}$ elected representatives at legislative hearings ${ }^{284}$ and the media, ${ }^{285}$ the demonization of sex offenders has helped create a "moral panic" 286 that has driven the passage of legislation. ${ }^{287}$ The "anger and hostility the public feels"288

280 On the imprecision and overbreadth of this category, ranging from the stranger pedophiliac rapist to the teenager consensually "sexting" pictures of herself to her boyfriend, see Lucy Berliner, Sex Offenders: Policy and Practice, 92 Nw. U. L. REV. 1203, 1208 (1998) ("[S]ex offenders do not share a common set of psychological and behavioral characteristics.”). See also ALA. CODE § 13A-12-131 (2014) (criminalizing the display of obscene bumper stickers descriptive of "sexual or excretory activities" as a misdemeanor). See generally Cucolo \& Perlin, supra note 56, at 21 (discussing the current system which "bundles statutory rape cases that deal with sexual interactions between teenagers - interactions that would otherwise be consensual but for the age of one of the partners-with cases of individuals who have committed violent pedophilic offenses"). On the incoherence of laws governing adolescent sexuality, see generally Michelle Oberman, Two Truths and a Lie: In re John Z. and Other Stories at the Juncture of Teen Sex and the Law, 38 LAW \& SOC. INQUIRY 364 (2013). On juveniles and sex offenses generally, see generally Carissa Byrne Hessick \& Judith M. Stinson, Juveniles, Sex Offenses, and the Scope of Substantive Law, 46 TEXAS TECH L. REV. 5 (2013).

281 Perlin, supra note 31, at 1248 ("If we are no longer focusing on insanity defendants as the most 'despised' group in society, it is more likely because there is a new universe of 'monsters' replacing them in our demonology: sex offenders, known variously, as mentally disordered sex offenders, or sexually violent predators, the ultimate 'other."') See also Eric J. Buske, Sex Offenders Are Different: Extending Graham to Categorically Protect the Less Culpable, 89 WASH. U. L. REV. 417, 433 (2011).

282 We have yet to find an appellate reversal of a case in which this inflammatory language was used. See, e.g., Comer v. Schriro, 463 F.3d 934, 960 (9th Cir. 2006); Kellogg v. Skon, 176 F.3d 447, 451 -52 (8th Cir. 1999); Jackson v. Ludwick, No. 2:09-CV-11928, 2011 WL 4374281, at *11 (E.D. Mich. Sept. 20, 2011); State v. Henry, 102 So.3d 1016, 1024 (La. Ct. App. 2012); Bonner v. State, No. 10-09-00120-CR, 2010 WL 3503858, at *4 (Tex. Ct. App. Sept. 8, 2010).

283 See, e.g., People v. Ball, No. 295851, 2011 WL 1086557, at*3 (Mich. Ct. App. Mar. 24, 2011).

284 See, e.g., Timothy E. Wind, The Quandary of Megan's Law: When the Child Sex Offender Is a Child, 37 J. Marshall L. ReV. 73, 92 (2003) (quoting Rep. Mark Green); Daniel M. Filler, Making the Case for Megan's Law: A Study in Legislative Rhetoric, 76 IND. L.J. 315, 339 (2001) (quoting Senator Kay Bailey Hutchison).

285 See, e.g., Rachel J. Rodriguez, The Sex Offender Under the Bridge: Has Megan's Law Run Amok?, 62 Rutgers L. ReV. 1023, 1031-32 (2010) (quoting John G. Winder, The Monster Next Door: The Plague of American Sex Offenders, CYPRESS TIMES, Nov. 20, 2009 (“"There's no such thing as monsters.' We tell our kids that. The truth is that monsters are real. ... These monsters are called 'Sex Offenders'....”)).

286 See, e.g., Filler, supra note 284; Eric M. Fink, Liars and Terrorists and Judges, Oh My: Moral Panic and the Symbolic Politics of Appellate Review in Asylum Cases, 83 Notre Dame L. ReV. 2019, 2038-39 (2008); Eamonn Carrabine, Crime, Culture and the Media in a Globalizing World, in ROUTLEDGE HANDBOOK OF INTERNATIONAL CRIME \& Justice Studies 397, 401 (Bruce A. Arrigo \& Heather Y. Bersot, eds., 2014); Stanley Cohen, Folk Devils \& MORAL PANICS 1 (3d ed. 2002).

287 On "legislative panic" in this context, see Wayne A. Logan, Megan's Laws as a Case Study in Political Stasis, 61 SyracuSe L. ReV. 371, 371 (2011); Deborah W. Denno, Life Before the Modern Sex Offender Statutes, 92 Nw. U. L. REV. 1317, 1320 (1998). On "judicial panic" in the context of same-sex marriage cases, see John G. Culhane, Uprooting the Arguments Against Same-Sex Marriage, 20 CARDOZO L. REV. 1119, 1146 (1999).

288 Meghan Gilligan, Note, It's Not Popular But It Sure Is Right: The (In)Admissibility of Statements Made Pursuant to Sexual Offender Treatment Programs, 62 SYRACUSE L. REV. 255, 271 (2012). 
about this population has been reflected in judicial decisions, at the trial, intermediate appellate and Supreme Court levels. ${ }^{289}$ The emerging laws and legislation have been more often than not found to be counter-productive and engendering a more dangerous set of conditions. ${ }^{290}$ As the authors have reiterated in prior articles, ${ }^{291}$ the term "sexually violent predator" is itself "an emotionally charged one that conjures up many misleading or inaccurate images." 292

Categorizing this population as the "most despised" has no doubt had a direct effect on the quality and availability of counsel for these individuals. Regardless of an attorney's principled intentions, the emotional response generated from these types of crimes can have a detrimental effect on the quality of representation. Once again, the emphasis on ability of counsel cannot be undermined when we are considering an absolute right to counsel.

\section{The Need for a More Rigorous Advocacy Standard}

In short, the simple assignment of counsel will not provide adequate representation by any metric. ${ }^{293}$ Judge David Bazelon's characterization of many of the lawyers who appeared before him as "walking violations of the Sixth Amendment," ${ }^{294}$ referred to in the Introduction to this Article, still unfortunately resonates after four decades. The special confounding issues presented in these cases - the pretextuality of the entire SVPA process, ${ }^{295}$ the fact that most lawyers are not familiar with the psychometric tests that are at the heart of these proceedings, the failure of courts to extend the Ake v. Oklahoma ruling to such cases, and the level of hatred directed at this cohort of individuals as well as to their lawyers - demand a standard more rigorous than the pallid one presented in Strickland. ${ }^{296}$

289 For one striking example, see Perlin \& Weinstein, supra note 60 (discussing a trial judge in one sex offender case who said, about persons who molest children, "It is my feeling that we should probably dye them green" (citing Leonore H. Tavill, Scarlet Letter Punishment: Yesterday's Outlawed Penalty Is Today's Probation Condition, 36 CleV. ST. L. ReV. 613, 644 n.193 (1988))).

$290 \quad$ Cucolo \& Perlin, supra note 56, at 5.

291 Id. at 2; Cucolo \& Perlin, supra note 59, at 186.

292 Cucolo \& Perlin, supra note 56, at 2 (discussing Adam Deming, Sex Offender Civil Commitment Programs: Current Practices, Characteristics, and Resident Demographics, 36 J. PSYCHIATRY \& L. 439, 443 (2008)).

293 On the additional problems raised by the "status quo bias" of the criminal justice system, see Andrew E. Taslitz, Trying Not to Be Like Sisyphus: Can Defense Counsel Overcome Pervasive Status Quo Bias in the Criminal Justice System?, 45 TEX. TECH L. REV. 315 (2012).

294 Bazelon, supra note 18 , at 2.

295 See generally Perlin, supra note 31.

296 A state court system, under the aegis of the Administrative Office of Courts, could certainly promulgate practice standards demanding an enhanced level of competency for attorneys representing defendants in such cases. We wish to thank our colleague Professor Rick Marsico for this helpful suggestion. 


\section{THERAPEUTIC JURISPRUDENCE ${ }^{297}$}

One of the most important legal theoretical developments of the past two decades has been the creation of therapeutic jurisprudence ("TJ") ... [TJ] assess[es] the impact of case law and legislation, recognizing that, as a therapeutic agent, the law... can have therapeutic or anti-therapeutic consequences. The ultimate aim of $[\mathrm{TJ}]$ is to determine whether legal rules, procedures, and the role of lawyers can or should be reshaped to enhance their therapeutic potential while not subordinating due process principles. David Wexler identifies how the inherent tension in this inquiry must be resolved: "[T]he law's use of mental health information to improve therapeutic functioning [cannot] impinge upon justice concerns." As one of the authors of this article (MLP) has written elsewhere, "[a]n inquiry into therapeutic outcomes does not mean that 'therapeutic concerns 'trump' civil rights and civil liberties." 298

Therapeutic jurisprudence "asks us to look at law as it actually impacts people's lives" and focuses on the law's influence on emotional life and psychological well-being. It suggests that "law should value psychological health, should strive to avoid imposing anti-therapeutic consequences whenever possible, and when consistent with other values served by law[,] should attempt to bring about healing and wellness." 299

$\cdots$

... In its aim to use the law to empower individuals, enhance rights, and promote well-being, therapeutic jurisprudence has been described as "a seachange in ethical thinking about the role of law ... a movement towards a more distinctly relational approach to the practice of law... which emphasizes psychological wellness over adversarial triumphalism." Accordingly, therapeutic jurisprudence supports an ethic of care. ${ }^{300}$

297 The quotations in this section have been excerpted from Michael L. Perlin \& Meredith R. Schriver, "You That Hide Behind Walls": The Relationship between the Convention on the Rights of Persons with Disabilities and the Convention Against Torture and the Treatment of Institutionalized Forensic Patients, in TORTURE IN HEALTHCARE

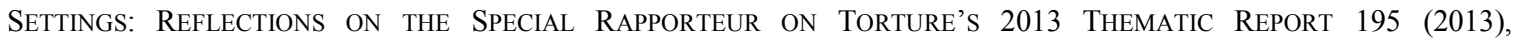
http://antitorture.org/wp-content/uploads/2014/03/PDF_Torture_in_Healthcare_Publication.pdf, and generally adapted from Michael L. Perlin, "Striking for the Guardians and Protectors of the Mind": The Convention on the Rights of Persons with Mental Disabilities and the Future of Guardianship Law, 117 PENN ST. L. REV. 1159 (2013).

298 Perlin \& Schriver, supra note 297, at 213-14 (citations omitted); see Perlin, supra note 297, at 1183-84.

299 Perlin \& Schriver, supra note 297, at 214 (citations omitted); see Perlin, supra note 297, at 1185.

300 Perlin \& Schriver, supra note 297, at 214-15 (citations omitted); see Perlin, supra note 297, at 1186. 
One of the central principles of therapeutic jurisprudence is a commitment to dignity. Professor Amy Ronner describes the "three Vs": voice, validation[,] and voluntariness, arguing ${ }^{301}$ :

What "the three Vs" commend is pretty basic: litigants must have a sense of voice or a chance to tell their story to a decision maker. If that litigant feels that the tribunal has genuinely listened to, heard, and taken seriously the litigant's story, the litigant feels a sense of validation. When litigants emerge from a legal proceeding with a sense of voice and validation, they are more at peace with the outcome. Voice and validation create a sense of voluntary participation, one in which the litigant experiences the proceeding as less coercive. Specifically, the feeling on the part of litigants that they voluntarily partook in the very process that engendered the end result or the very judicial pronunciation that affects their own lives can initiate healing and bring about improved behavior in the future. In general, human beings prosper when they feel that they are making, or at least participating in, their own decisions. ${ }^{302}$

The question to be posed here is this: to what extent can therapeutic jurisprudence better inform legal practices to ensure that adequate counsel is provided to persons at SVP hearings in such a way that these principles written about by Professor Ronner-the principles of voluntariness, voice, and validation - can be honored?

Although there has been important scholarly inquiry into the question of the relationship between $\mathrm{TJ}$ and the sex offender process in general, ${ }^{303}$ limited attention has been paid to the question before us here. ${ }^{304}$ What the substantive SVPA case law tells us, though, underscores the positive and essential relationship between adequate counsel and TJ in this context. Those very

\footnotetext{
301 Perlin \& Schriver, supra note 297, at 215 (citations omitted); see Perlin, supra note 297, at 1186.

302 Id. (quoting Amy D. Ronner, Songs of Validation, Voice, and Voluntary Participation: Therapeutic Jurisprudence, Miranda and Juveniles, 71 U. CIN. L. REV. 89, 94-95 (2002)).

303 We discuss some of this literature in Cucolo \& Perlin, supra note 56. See, e.g., John Q. La Fond, Can Therapeutic Jurisprudence Be Normatively Neutral? Sexual Predator Laws: Their Impact on Participants and Policy, 41 ARIZ. L. ReV. 375, 377 (1999); Katie Granlund, Does Societal Input Lead to Successful Sex Offender Legislation?, 29 LAw \& Psychol. ReV. 197 (2005); Bruce J. Winick, Sex Offender Law in the 1990s: A Therapeutic Jurisprudence Analysis, 4 PSYCHOL. PUB. POL’Y \& L. 505, 506 (1998).
}

304 But see Dale Dewhurst, Understanding the Legal Client's Best Interests: Lessons from Therapeutic Jurisprudence and Comprehensive Justice, 6 PHOENIX L. REV. 963, 998-1003 (2013).

For a discussion of therapeutic jurisprudence and lawyers' roles in general, see Cucolo \& Perlin, supra note 56; Michael L. Perlin, “And My Best Friend, My Doctor/Won't Even Say What It Is I've Got”: The Role and Significance of Counsel in Right to Refuse Treatment Cases, 42 SAN DIEGO L. REV. 735, 750 (2005).

See also Janet B. Abisch, Mediational Lawyering in the Civil Commitment Context: A Therapeutic Jurisprudence Solution to the Counsel Role Dilemma, 1 PSYCHOL. PUB. POL'Y \& L. 120, 122 (1995) (discussing mediational lawyering in the civil commitment context); Jan C. Costello, "Why Would I Need a Lawyer?" Legal Counsel and Advocacy for People with Mental Disabilities, in Law, Mental Health, \& Mental Disorder 15 (Bruce D. Sales \& Daniel W. Shuman eds., 1996); Keri A. Gould, A Therapeutic Jurisprudence Analysis of Competency Evaluation Requests: The Defense Attorney's Dilemma, 18 InT'L J.L. \& PSYCHIATRY 83, 95-96 (1995). 
variables that make SVPA litigation different - the need for lawyers to be able to understand, contextualize and effectively cross-examine experts on specific actuarial tests; the need for lawyers to recognize when an expert witness is needed to rebut the state's position, and the need for lawyers to understand the potential extent of jury bias (making the ideal of a fair trial even more difficult to accomplish) - all demand a TJ approach to representation and to litigation. Certainly, even a cursory examination of SVPA cases litigated on the right-to-counsel issue 305 demonstrate beyond any doubt that the "voice" required in Professor Ronner's formulation of TJ is missing, and that we have no basis on which to make a reasoned conclusion as to whether "validity" is present. This is all the more important since the notion of "voluntariness" is certainly absent. ${ }^{306}$

Looking at this question recently, Professor Dale Dewhurst concluded that, from a TJ perspective, lawyers must be able to engage with other behavioral experts in SVPA cases so as to provide adequate representation for their clients and-optimally- to share with the court treatment models that reject the current punitive measures that do not reduce recidivism. ${ }^{307}$ If counsel were familiar with such approaches as the Risk-Needs-Responsibility Model or the Good Lives model ${ }^{308}$ _embodying approaches that go "beyond the legalistic skills of the lawyers" 309 she would best embody the TJ value of "zealous counseling" urged by Robert Ward. ${ }^{310}$

In short, TJ is completely absent from these proceedings. We believe that adoption of our effectiveness-of-counsel remedy might be the most important way of remediating this absence.

\section{CONCLUSION}

When we presented a version of this Article at a faculty workshop, friends and colleagues, including those whose careers have been devoted to representing marginalized populations, told us that they found some of what we reported on "almost unbelievable." We were not surprised. What we have reported on here exists under the radar for almost all attorneyseven progressive attorneys-who do not focus on these cases. So it is no surprise that these issues have remained unconsidered by courts and by scholars alike.

What we have reported on is woeful. Again, perhaps more woeful is the fact that this entire issue is ignored in the public debate. We believe, however, that if the right to counsel were

305 See supra Part I.

306 See Ronner, supra note 302.

307 Dewhurst, supra note 304, at 1000 (citing DORIS LAYTON MACKENZIE, WHAT WoRKS IN Corrections: Reducing the CRiminal Activities of OfFenders \& Delinquents 333-34 (2006)). See, e.g., Grant Duwe, To What Extent Does Civil Commitment Reduce Sexual Recidivism? Estimating the Selective Incapacitation Effects in Minnesota, 42 J. CRIM. JUST. 193 (2014) (discussing a Minnesota state study that concluded that just nine percent of civilly-committed sex offenders would have been reconvicted of a new sex offense within four years had they been released to the community).

308 See Dewhurst, supra note 304, at 1000-02 (citing, inter alia, TONY WARD \& SHADD MARUNA, Rehabilitation: Beyond the Risk PARAdigm 46 (2007), and Astrid Birgden, Therapeutic Jurisprudence and Sex Offenders: A Psycho-Legal Approach to Protection, 16 SeXUAL ABUSE: J. Res. \& TREATMENT 351, 360 (2004)).

309 Dewhurst, supra note 304, at 1002.

310 Id. at 971 (quoting Robert Ward, Criminal Defense Practice and Therapeutic Jurisprudence: Zealous Advocacy through Zealous Counseling: Perspectives, Plans and Policy, in ReHABILITATING LAWYers: PrinCIPLES OF THERAPEUTIC JURISPRUdENCE FOR CRIMINAL LAW PRACTICE 206 (David B. Wexler ed., 2008)). 
to be made mandatory in all SVP cases, and if the standard of adequacy of counsel in such cases was to be enhanced (as the Montana Supreme Court did in "regular" civil commitment cases in K.G.F.), ${ }^{311}$ then counsel would be more likely to be effective, and that the underlying proceedings would have at least a patina of fairness.

Recall what Dylan critic Michael Gray had to say about Jokerman, the song from which the first part of the title of this article is derived: "'[E]vil' is not 'out there,' 'among the others,' but is inside us all." ${ }^{\prime 312}$ By depicting sex offenders as "monsters," ${ }^{\prime 313}$ we ignore this, which allows us to ignore the realities of the SVPA process and the need for effective counsel. It is time to stop ignoring these realities.

311 See In re K.G.F., 29 P.3d at 497-498; see also text accompanying notes 22-25, supra.

312 GRAY, supra note 61 , at 364.

313 See, e.g., Kenneth Dowler, Media Consumption and Public Attitudes Toward Crime and Justice: The Relationship Between Fear of Crime, Punitive Attitudes, and Perceived Police Effectiveness, 10 J. CRIM. JUST. \& POPULAR Culture 109, 120 (2003). 